\title{
Transpressional granite-emplacement model: Structural and magnetic study of the Pan-African Bandja granitic pluton (West Cameroon)
}

\author{
A F Yakeu SAndjo ${ }^{1,2, *}$, T NJAnKo ${ }^{1,3}$, E NJonfang $^{4}$, E Errami $^{5}$, \\ P RochetTe ${ }^{6}$ and E Fozing ${ }^{1}$ \\ ${ }^{1}$ Laboratory of Environmental Geology, University of Dschang, P.O. Box 67, Dschang, Cameroon. \\ ${ }^{2}$ Ministry of Water Resources and Energy, DR/C, Gas and Petroleum Products Service, \\ P.O. Box 8020, Yaoundé, Cameroon. \\ ${ }^{3}$ Ministry of Scientific Research and Innovation, DPSP/CCAR, P.O. Box 1457, Yaoundé, Cameroon. \\ ${ }^{4}$ Laboratory of Geology, ENS, The University of Yaoundé I, P.O. Box 47, Yaoundé, Cameroon. \\ ${ }^{5}$ Department of Geology, Faculty of Sciences, The Chouaïb Doukkali University of El Jadida, \\ P.O. Box 20, 24000 El Jadida, Morocco. \\ ${ }^{6}$ CEREGE UMR7330 Aix-Marseille Université CNRS, 13545 Aix-en-provence, France. \\ *Corresponding author.e-mail: angeyakeu1@gmail.com
}

The Pan-African NE-SW elongated Bandja granitic pluton, located at the western part of the Pan-African belt in Cameroon, is a K-feldspar megacryst granite. It is emplaced in banded gneiss and its NW border underwent mylonitization. The magmatic foliation shows NE-SW and NNE-SSW strike directions with moderate to strong dip respectively in its northern and central parts. This mostly, ferromagnetic granite displays magnetic fabrics carried by magnetite and characterized by (i) magnetic foliation with best poles at 295/34, 283/33 and 35/59 respectively in its northern, central and southern parts and (ii) a subhorizontal magnetic lineation with best line at 37/8, 191/9 and 267/22 respectively in the northern, central and southern parts. Magnetic lineation shows an ' $S$ ' shape trend that allows to (1) consider the complete emplacement and deformation of the pluton during the Pan-African $\mathrm{D}_{2}$ and $\mathrm{D}_{3}$ events which occurred in the Pan-African belt in Cameroon and (2) reorganize Pan-African ages from Nguiessi Tchakam et al. (1997) compared with those of the other granitic plutons in the belt as: $686 \pm 17 \mathrm{Ma}$ $(\mathrm{Rb} / \mathrm{Sr})$ for $\mathrm{D}_{1}$ age of metamorphism recorded in gneiss; and the period between $604-557 \mathrm{Ma}$ for $\mathrm{D}_{2}-\mathrm{D}_{3}$ emplacement and deformation age of the granitic pluton in a dextral ENE-WSW shear movement.

\section{Introduction}

Spatial and temporal relationships between granites and regional tectonic structures suggest granite emplacement during compression rather than extension in many convergent orogenic belts (Hutton 1997; Brown and Solar 1998). Granite emplacement and deformation during regional tectonic events is a challenging study, because granitic rocks do not always develop mesoscopic scale deformation fabrics. However, microstructural studies of granites can help to identify magmatic or solid-state deformation fabrics (Simpson 1985; Paterson et al. 1989; Bouchez et al. 1992).

Detailed lithotectonic study of the Pan-African orogeny (mainly along the $\mathrm{N}-\mathrm{S}, \mathrm{N} 30^{\circ} \mathrm{E}$ and $\mathrm{N} 70^{\circ} \mathrm{E}$

Keywords. Granite; AMS; Pan-African; Bandja; Cameroon. 
shear zones) in Cameroon (figure 1) reveals that it is marked by the emplacement of many plutonic massifs of granitic composition. The petrology and mesoscopic to microscopic structural features of a few granites have been studied (the Ngondo plutonic complex, the west-Tibati pluton, the two-mica granites from the Nkambé area and the Fomopéa granitic pluton (figure 2), respectively by TagnéKamga (2003), Njanko et al. (2006), Tetsopgang et al. (2006) and Kwékam et al. (2010). However, their tectonic evolution remains poorly understood, due to lack of detailed structural data (e.g., anisotropy of magnetic susceptibility study on rocks). Indeed, the application of the anisotropy

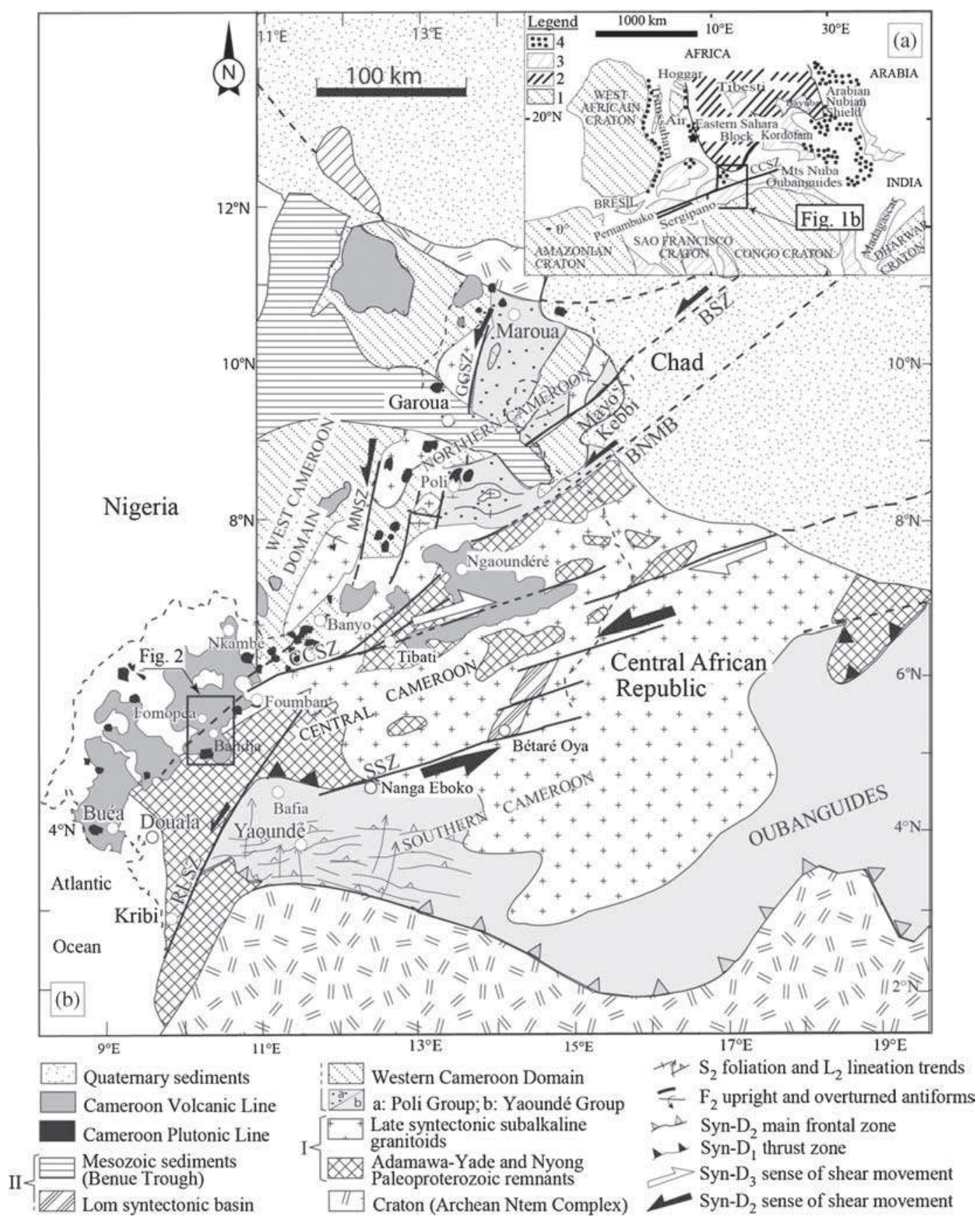

Figure 1. (a) Geological sketch map of Central-North Africa (western Gondwana) (Ngako et al. 2008; redrawn and reinterpreted from Küster and Liegeois 2001); 1 = Craton; 2 = Inferred Craton; 3 = Pan-African remobilization; $4=$ Neoproterozoic juvenile crust; (b) Pan-African structural map of Cameroon (Ngako et al. 2008; modified and re-interpreted from Toteu et al. 2001). Large grey arrow represents syn- $\mathrm{D}_{1-3}$ regional main stress direction. Thick lines = shear zone (SZ): BSZ = Balché SZ; BNMB = Buffle Noir-Mayo Baléo; CCSZ = Central Cameroon SZ; GGSZ = Godé-Gormaya SZ; MNSZ = Mayo Nolti SZ; RLSZ = Rocher du Loup SZ; SSZ = Sanaga SZ. I: Paleo-proterozoic basement and Pan-African syntectonic granitoids; II: Meso- to Neoproterozoic vocano-sedimentary basins. 


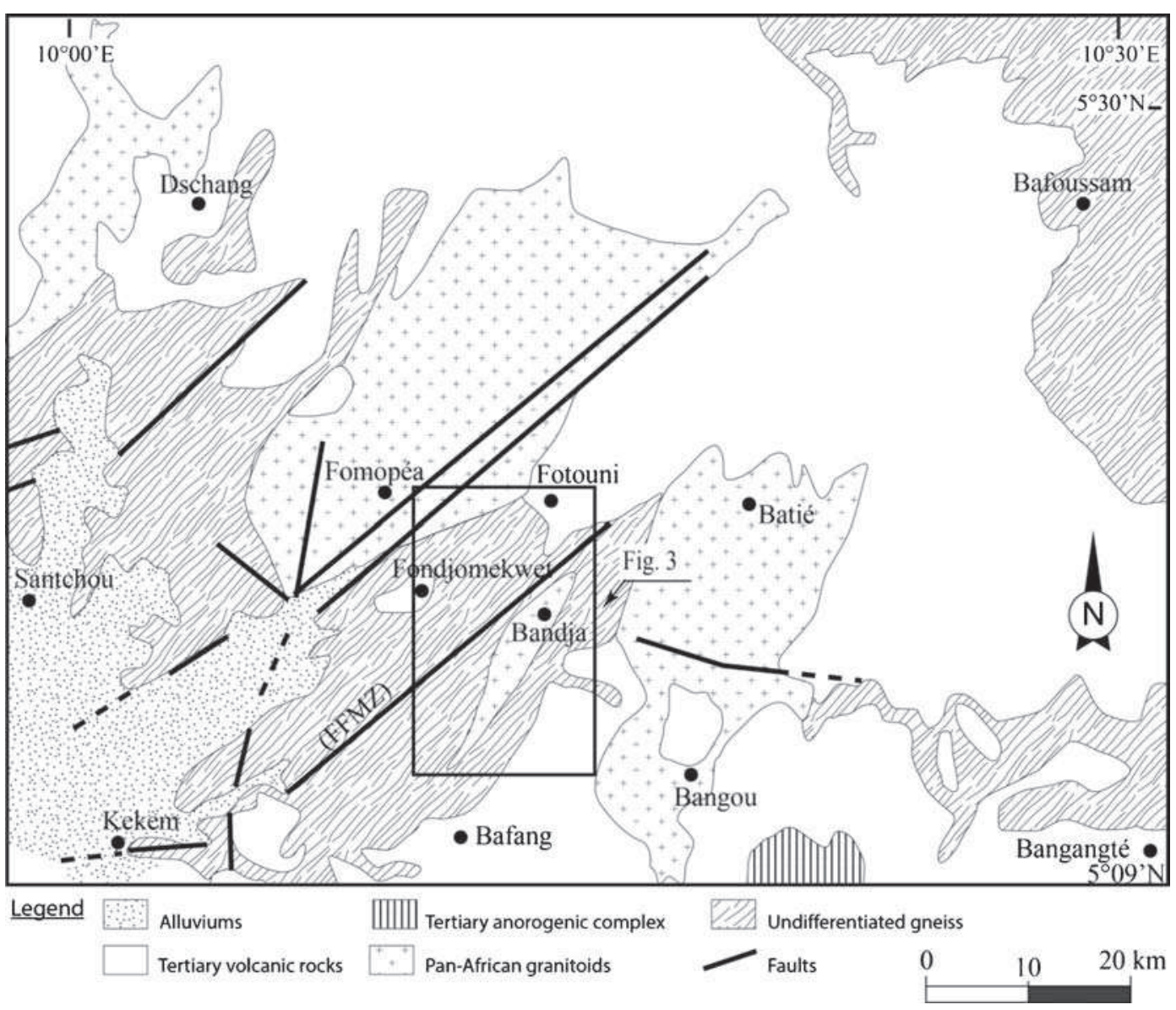

Figure 2. West Cameroon geological map showing the Bandja granitic pluton and neighbouring (Fomopéa and BatiéBangou) plutons (Dumort 1968).

of magnetic susceptibility (AMS) to the study of granitoids has led to a better understanding of the tectonic history of plutons elsewhere and recently in Cameroon (Kankeu et al. 2009; Njanko et al. 2010; Kankeu et al. 2012; Dawaï et al. 2013). Moreover, AMS is a widely accepted technique and a number of studies have investigated the relationship between AMS fabric and strain (Hrouda and Janak 1976; Borradaile 1988; Rochette et al. 1992; Tarling and Hrouda 1993; Borradaile and Henry 1997; Mamtani et al. 1999).

The aim of this paper is to combine field structures, microstructures and magnetic data to reconstruct the kinematic of emplacement of the Bandja Pan-African pluton and show its role in the PanAfrican history of the west Cameroon.

\section{Regional geological setting}

\subsection{The Pan-African belt in Cameroon}

The Pan-African orogenic belt of Cameroon (figure 1) is one of the two main domains (together with the Archaean Ntem Complex) proposed by previous research works for the Precambrian basement rocks in Cameroon. It is characterized by medium- to high-grade metamorphism, polycyclic deformation, possible reworking of older crust and generation of new granitic magmas. The Pan-African orogenic belt is also known as Pan-African North Equatorial Fold Belt (Nzenti et al. 1988) or Pan-African Belt of Central Africa (PBCA; Penaye et al. 1993; Toteu et al. 2001).

According to Ngako and Njonfang (2011), PBCA is a three-plate collision belt involving three major landmasses. The model proposed by these authors includes: the São-Francisco-Congo Craton (SFCC), the Eastern Saharan Block (ESB) and the West African Craton (WAC) (figure 1a). Collision in the north-south direction involved ESB and the northern margin of the SFCC originally differentiated into a basin and a range province. This collision generated an indent and intense deformation in the Cameroon domain (PBCA), following penetration of the Saharan rigid prong into the SFCC active margin between 640 and $580 \mathrm{Ma}$ (Ngako and Njonfang 2011). Successive tectonic events recorded in this active margin involved: (i) crustal thickening, (ii) left- and right-lateral conjugate wrench movements, and (iii) right-lateral wrench 
movements in the $\mathrm{N} 70^{\circ} \mathrm{E}$ to $\mathrm{EW}$ direction. According to Ngako and Njonfang (2011), structural and kinematic data show that, although collision between the Trans-Sahara active margin and the WAC started at ca. $630 \mathrm{Ma}$, deformation in northwestern Cameroon was mostly controlled by a NNE-SSW stress direction until ca. 590 Ma. Further deformation in this domain is recorded by a regional clockwise rotation compatible with a NWSE stress direction suggesting that the late tectonic event was the only one controlled by the prominent active role of the WAC.

PBCA comprises three lithotectonic domains (figure 1b): the northern Cameroon domain, the central Cameroon domain and the southern Cameroon domain.

The northern Cameroon domain or Poli Group, also known as west Cameroon domain (WCD, figure 1b; Toteu et al. 2004; Penaye et al. 2006) is limited to the south by the Buffle Noir-Mayo Baléo (BNMB) shear zone. It is characterized by Meso- to Neo-proterozoic volcano-sedimentary basins that were deformed and metamorphosed into schists and high-grade gneisses (Nzenti et al. 1988). It represents an early Neoproterozoic back-arc basin formed between 830 and $665 \mathrm{Ma}$ (Toteu et al. 1990, 2006; Penaye et al. 2006), that includes: detrital and volcaniclastic deposits, metavolcanics (tholeitic basalts and calc-alkaline rhyolites), and pre-, syn- to late-tectonic calk-alkaline intrusions (diorites, granodiorites and granites). These intrusions, emplaced between 660 and $580 \mathrm{Ma}$ (Toteu et al. 2001), form a NNE-SSW corridor.

The central Cameroon domain, to which belongs the Bandja pluton, also known as Adamawa domain, is located between the BNMB shear zone to the north and the Sanaga shear zone (SSZ) to the south (figure 1b). It includes huge Pan-African batholiths and large scale Paleoproterozoic remnants that were emplaced and metamorphosed during the Pan-African tectonic evolution. Massifs are often made up of syntectonic granitoids.

The southern Cameroon domain is limited to the north by the Sanaga shear zone to the south it thrusts onto the Congo Craton. This domain represents a syntectonic basin, for which deposition age is younger than $625 \mathrm{Ma}$ (U-Pb dating of detrital zircons, Toteu et al. 2006). It includes metasediments (shales, greywackes, minor quartzites, dolomites and evaporites) and pre- to syn-tectonic alkaline to transitional intrusions represented by pyroxenites, pyroxene-amphibole and pyroxene-plagioclase rocks (Nzenti 1998); scarce outcrops of serpentinized ultramafic rocks associated with gabbros, diorites and mafic dykes are also found (Seme Mouangue 1998; Nkoumbou et al. 2006). All these rocks were metamorphosed in the HP-HT granulite facies at ca. $620 \mathrm{Ma}$ (U-Pb zircon age by Penaye et al. 1993) prior to exhumation and thrusting over the Congo craton.

Many authors have proposed models to explain the emplacement of granitoids within the PanAfrican belt. These models evoke the transpressional context (Njiékak et al. 2008 for the Batié granitic complex, Djouka-Fonkwé et al. (2008) for the Bafoussam granitoids, Kankeu et al. (2009) for the Lom basin granites) as well as the transtensional context (Nguiessi Tchakam et al. (1997) for the Bandja magmatic complex, Tagné Kamga (2003) for the Ngondo plutonic complex, Tchameni et al. (2006) for the Ngaoundéré Pan-African granitoids, and Kwékam et al. (2010) for the Fomopéa Pan-African plutonic complex) for granitoids emplacement.

\subsection{Geology and geochronology of the area}

The west Cameroon region (figure 2) is underlined by pre-, syn- to post-tectonic granitoids that have been subdivided into three main types, based on their relationships with orogenic deformational phases:

(1) 630-620 Ma pre- to syn- $D_{1}$ granitoids;

(2) 600-580 Ma syn- $\mathrm{D}_{2}$ granitoids; and

(3) 550 Ma post-orogenic granitoids (U/Pb ages, Toteu et al. 2001).

Using CHIME (chemical Th-U-total Pb isochron method) on zircon and allanite crystals in rocks, Tetsopgang et al. (1999, 2008), in the Nkambé granitoids, determined an age of $532 \pm 35$ Ma on allanite and $523 \pm 45 \mathrm{Ma}$ on zircon in the biotite hornblende orthogneiss and an age of $569 \pm 12 \mathrm{Ma}$ in hornblende-biotite granite. Tagné Kamga (2003) in the Ngondo plutonic complex suggests an older continental crust during the genesis of the magma with little or no addition of mantle derived magma to the crust for the $600 \mathrm{Ma}$ granitoids. Tchameni et al. (2006) obtained ca. 615-575 Ma (Th-U-Pb age on monazite) on the Ngaoundéré granitoids and suggested a differentiation of mafic magma from an enriched subcontinental lithospheric mantle with possible crustal assimilation. Njiékak et al. (2008) determined in the Bangou-Batié granitic pluton $632-602 \mathrm{Ma}(\mathrm{U}-\mathrm{Pb}$ on zircon) and proposed a syn-kinematic emplacement of the pluton along a crustal scale NNE to ENE trending strike-slip shear zone. Kwékam et al. (2010) obtained U-Pb ages of 621-613 Ma on the Fomopéa granitic complex and proposed a model whereby linear lithospheric delamination occurred along the Central Cameroon Shear Zone (CCSZ) in response to post-collisional transpression. This delamination induced the partial melting of the mantle and old lower crust. According to these latter authors, the 
emplacement of numerous post-collisional Neoproterozoic plutons along the CCSZ during the PanAfrican orogeny indicates that this process was of paramount importance. Recent research works of Dawaï et al. (2013) and Mosoh Bambi et al. (2013) respectively, for the Guider quartz-syenite (northern Cameroon) and Ekomédion granites (southwestern Cameroon) determined a U-Pb age of 593 Ma on zircon in quartz-syenite and 578 Ma in granites. (Mosoh Bambi et al. 2013 concluded for a crustal origin of the magma.)

These granitoids, cross-cut by gabbroic dykes (Kwékam et al. 2010), are partially covered with basaltic and trachytic lavas. Early data from the granitoids yielded ages in the 550-700 Ma range
(Nguiessi Tchakam and Vialette 1994; DjoukaFonkwé et al. 2008; Njiékak et al. 2008; Kwékam et al. 2010). Recent $\mathrm{Th}-\mathrm{U}-\mathrm{Pb}$ monazite dating in the Bafoussam region by Djouka-Fonkwé et al. (2008) yielded 558-564 Ma emplacement ages of two mica granitoids. The metamorphic host rocks, orthogneiss (hornblende-biotite gneiss) and amphibolites were reworked during the Pan-African orogeny (Njiékak et al. 2008; Kwékam et al. 2010).

The Bandja granitic pluton has NE-SW elongated shape with a long axis around $25 \mathrm{~km}$ and a short axis not more than $6 \mathrm{~km}$ (figure 3 ). Its outcrops cover roughly $80 \mathrm{~km}^{2}$. Outcrops are of variable quality and granites often correspond to topographic elevations. Outcrops of the gneissic

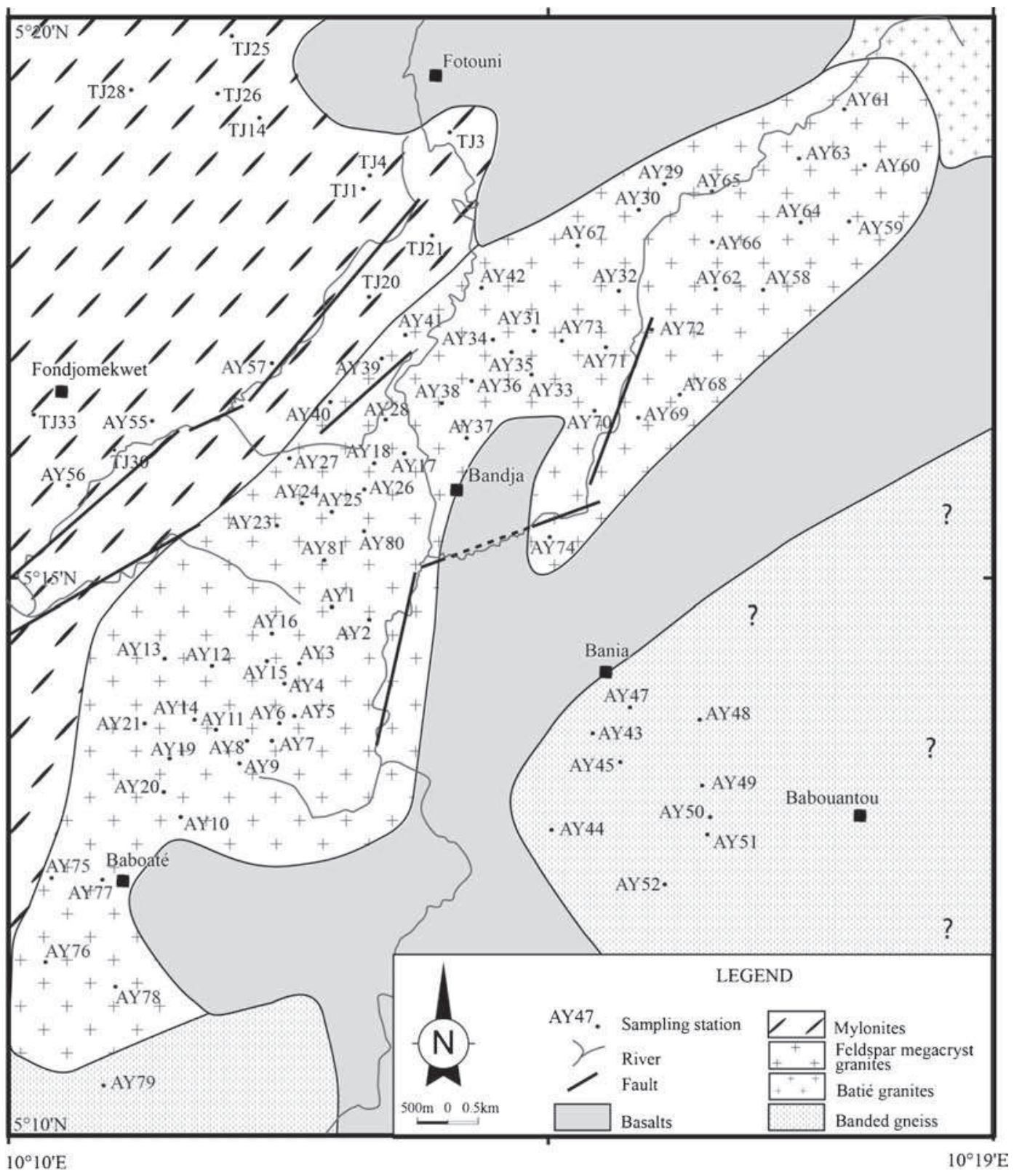

Figure 3. Geological map of the study area showing the sampled sites. 
basement are scarce, and contacts with the pluton are generally lacking.

Dumort (1968) represents the Bandja granitic pluton as a sheet of magmatic rock that comprises a porphyritic facies at its northeastern part, while its southwestern part is made of anatexitic rocks (figure 2). It is stuck between the Fomopéa granitic pluton (Kwékam et al. 2010; Njanko et al. 2010) and the Bangou-Baham porphyritic granitic pluton. It is affected at its western border by the ductile Fotouni-Fondjomekwet mylonitic zone (FFMZ; Njanko et al. 2010). The Bandja granitic pluton is dominantly porphyritic in nature. According to Nguiessi Tchakam et al. (1997), it comprises two rock groups: (i) a highly deformed group, including mylonites (called orthogneiss and charnokites) and banded gneiss, and (ii) a less deformed group including diorite, monzonite, granodiorite, alkali feldspar megacryst granite and fine-grained granite, the so-called Bandja porphyritic granite. In the field, this latter petrographic group is not really very well organized and distinctively mappable; those rocks are then regrouped under alkali feldspar megacryst granites.

According to Nguiessi Tchakam and Vialette (1994) and Nguiessi Tchakam et al. (1997), monzonite and granites from Bandja granitic pluton are metaluminous. The geochemical behaviour is consistent with (i) a common origin of these rocks and (ii) a potassic calc-alkaline magmatism of orogenic context, close to the syn-collisional to postcollisional domain (Pearce et al. 1984; Lagarde et al. 1992). The emplacement of orthogneiss is dated with an age of $686 \pm 17 \mathrm{Ma}(\mathrm{Rb} / \mathrm{Sr}$ ) (Lamilen $1989)$; an age of $640 \pm 15 \mathrm{Ma}(\mathrm{U} / \mathrm{Pb}, \mathrm{Pb} / \mathrm{Pb}$ on zircons) dates the emplacement of charnockites; and an age of $557 \pm 8 \mathrm{Ma}(\mathrm{Rb} / \mathrm{Sr})$ dates the emplacement of K-feldspar megacryst granites (Nguiessi Tchakam and Vialette 1994). These ages are similar to those of syntectonic rocks of the Pan-African belt (604 Ma; Penaye et al. 1993) and give a good relation between different Pan-African phases of deformation: 687-633 Ma (earlier-D $\left.\mathrm{D}_{1}\right), 604-580 \mathrm{Ma}$ $\left(\right.$ syn- $\left.\mathrm{D}_{2}\right)$ and late at $557 \mathrm{Ma}$ (Penaye et al. 1993).

\section{Materials and methods}

In this study, we use classical field methods and anisotropy of magnetic susceptibility (AMS) method.

Oriented cylinder samples were drilled, directly in the field, from 88 different sites (figure 3) distributed among the granitic pluton, the mylonitic zone and the banded gneiss of the country rocks: 64 sites in feldspar megacryst granites, 14 sites in mylonites and 10 sites from banded gneiss. A total of 363 specimens have been analyzed in this study.
In classical field method, the petrography is carried out using thin sections from remaining oriented cores sampled for AMS study. Structural elements and kinematic indicators (folds, foliations, stretching lineations, S-C structures, ...) are recognizable at a metric or centimetric scale and can be used to infer the kinematic during the emplacement. These data were statistically analyzed using Stereonet software (Allmendinger's Stereonet program) with conventional techniques.

Today, measurement of AMS is a structural analysis powerful tool (Bouchez 1997, 2000) to determine petrofabric orientation in rocks, even in rocks that are visually isotropic. AMS principles are described in various research works (Borradaile and Henry 1997; Bouchez 1997, 2000). We, therefore present here elements to understand the emplacement of Bandja magmatic complex.

Two or three oriented cores were collected at each site. Each core yielded at least two cylindrical samples, hence providing an average of four specimens per site. Each individual sample is $22 \mathrm{~mm}$ in length and $25 \mathrm{~mm}$ in diameter (the standard size for magnetic measurements). AMS measurements were then performed on a Kappabridge susceptometer KLY-3S (Agico Ltd., Czeck Republic); working at a low alternating field $\left( \pm 4 \times 10^{-4} \mathrm{~T}\right.$, $920 \mathrm{~Hz}$ ) with a sensitivity of about $2 \times 10^{-7} \mathrm{SI}$, allowing anisotropy discrimination below $0.2 \%$ over a wide range of susceptibilities. The orientations of the principal axes $\mathrm{K}_{i}(i=1$ to 3$)$ of the average AMS ellipsoid for a given site are obtained by a classical eigenvector calculation between the individual AMS measurements $\mathrm{K}_{i j}$ (specimens $j=1-4)$. The magnetic susceptibility is measured for different orientations of the cylindrical specimen and is used to calculate the intensity of the three principal axes of the magnetic susceptibility ellipsoid $K_{1}, K_{2}$ and $K_{3}$. AMS is a second-rank tensor expressed by its principal eigenvectors and eigenvalues $K_{\max }=K_{1}>K_{\text {int }}=$ $\mathrm{K}_{2}>\mathrm{K}_{\min }=\mathrm{K}_{3}$, respectively representing the maximum, intermediate and minimum axes of the magnetic susceptibility ellipsoid.

The long axis of the ellipsoid $K_{1}$ defines the magnetic lineation and the short axis $K_{3}$ defines the pole of the magnetic foliation (the plane formed by $\mathrm{K}_{1}$ and $\mathrm{K}_{2}$ axes). In plutonic rocks, the magnetic fabric is usually coaxial with the mineral fabric. When a granite has a so-called 'paramagnetic' behaviour, $K_{3}$ represents the pole of the foliation marked by the preferred orientation of the main Fe-bearing silicate mineral (namely biotite and amphibole), and $\mathrm{K}_{1}$ represents the biotite lineation defined as the axis of rotation, or zone axis, of the biotite foliation (Bouchez 2000). It is worth to notice that, in these rocks, very small quantity of ferromagnetic material may be present as 
Table 1. Summary of magnetic scalar and directional data on the Bandja granitic pluton. $K_{1}, K_{2}$ and $K_{3}$ are the maximum, intermediate and minimum susceptibility intensities respectively; $K m=\left(K_{1}+K_{2}+K_{3}\right) / 3$ is the mean magnetic susceptibility; $P^{\prime}$ is the anisotropy degree (Jelinek 1981), $T=\left(2 \ln \left(K_{2} / K_{3}\right) /\left(\ln \left(K_{1} / K_{3}\right)\right)-1\right)$ is the Jelinek's shape parameter (Jelinek 1981); $N$ is the number of analyzed specimens; Dec: declination in degrees; Inc: inclination in degrees.

\begin{tabular}{|c|c|c|c|c|c|c|c|c|c|c|c|c|}
\hline \multirow[b]{3}{*}{ Site } & \multirow[b]{3}{*}{ Lat. $N\left({ }^{\circ}\right)$} & \multirow[b]{3}{*}{ Long. $\mathrm{E}\left({ }^{\circ}\right)$} & \multirow[b]{3}{*}{$\mathrm{N}$} & \multicolumn{3}{|c|}{ Mean AMS parameters } & \multicolumn{6}{|c|}{ Mean eigenvectors } \\
\hline & & & & \multicolumn{3}{|l|}{$\mathrm{Km}\left(10^{-6}\right)$} & \multicolumn{2}{|c|}{$\mathrm{K}_{1}$} & \multicolumn{2}{|c|}{$\mathrm{K}_{2}$} & \multicolumn{2}{|c|}{$\mathrm{K}_{3}$} \\
\hline & & & & $(\mu \mathrm{SI})$ & $P^{\prime}$ & $T$ & $\operatorname{Dec}\left({ }^{\circ}\right)$ & $\operatorname{Inc}\left(^{\circ}\right)$ & $\operatorname{Dec}\left({ }^{\circ}\right)$ & $\operatorname{Inc}\left({ }^{\circ}\right)$ & $\operatorname{Dec}\left({ }^{\circ}\right)$ & $\operatorname{Inc}\left(^{\circ}\right.$ \\
\hline \multicolumn{13}{|c|}{ Mylonites } \\
\hline TJ1 & 5.3152 & 10.2322 & 4 & 406 & 1.18 & 0.06 & 207 & 7 & 314 & 68 & 115 & 22 \\
\hline TJ3 & 5.3166 & 10.2375 & 8 & 51 & 1.14 & 0.33 & 38 & 2 & 307 & 42 & 130 & 48 \\
\hline TJ4 & 5.3158 & 10.2322 & 4 & 1241 & 1.32 & 0.12 & 215 & 9 & 329 & 69 & 124 & 19 \\
\hline TJ14 & 5.32 & 10.2133 & 4 & 692 & 1.21 & 0.02 & 227 & 6 & 330 & 66 & 135 & 23 \\
\hline TJ20 & 5.2997 & 10.2327 & 4 & 13131 & 1.65 & 0.09 & 235 & 9 & 142 & 81 & 145 & 2 \\
\hline TJ21 & 5.303 & 10.2361 & 4 & 7285 & 1.64 & 0.22 & 22 & 2 & 117 & 70 & 289 & 20 \\
\hline TJ25 & 5.3347 & 10.2094 & 4 & 954 & 1.13 & 0.15 & 25 & 54 & 334 & 43 & 302 & 19 \\
\hline TJ26 & 5.328 & 10.2038 & 3 & 547 & 1.14 & 0.76 & 205 & 11 & 33 & 78 & 298 & 3 \\
\hline TJ28 & 5.3302 & 10.1922 & 4 & 1026 & 1.22 & 0.26 & 52 & 7 & 118 & 63 & 315 & 25 \\
\hline TJ30 & 5.2727 & 10.1897 & 4 & 337 & 1.06 & 0.20 & 220 & 15 & 316 & 49 & 127 & 50 \\
\hline TJ33 & 5.2811 & 10.1755 & 3 & 350 & 1.17 & 0.07 & 51 & 12 & 172 & 69 & 318 & 19 \\
\hline AY 55 & 5.2397 & 10.1905 & 4 & 278 & 1.10 & -0.64 & 39 & 3 & 136 & 73 & 307 & 17 \\
\hline AY56 & 5.2566 & 10.1722 & 4 & 322 & 1.10 & -0.21 & 40 & 4 & 306 & 52 & 133 & 37 \\
\hline AY57 & 5.2827 & 10.2125 & 4 & 311 & 1.09 & -0.60 & 53 & 4 & 204 & 86 & 323 & 2 \\
\hline \multicolumn{13}{|c|}{ Banded gneiss } \\
\hline AY43 & 5.2252 & 10.255 & 4 & 219 & 1.40 & 0.15 & 35 & 14 & 129 & 23 & 277 & 66 \\
\hline AY44 & 5.2072 & 10.2497 & 4 & 740 & 1.11 & -0.34 & 182 & 1 & 91 & 37 & 273 & 53 \\
\hline AY45 & 5.2208 & 10.2616 & 4 & 247 & 1.18 & -0.06 & 12 & 4 & 104 & 17 & 287 & 74 \\
\hline AY47 & 5.2288 & 10.2625 & 4 & 119 & 1.63 & 0.09 & 21 & 0 & 112 & 15 & 290 & 75 \\
\hline AY48 & 5.2275 & 10.2716 & 4 & 22463 & 1.78 & 0.66 & 1 & 6 & 105 & 67 & 269 & 22 \\
\hline AY49 & 5.2152 & 10.2722 & 4 & 390 & 1.09 & 0.37 & 176 & 3 & 82 & 25 & 274 & 65 \\
\hline AY50 & 5.2122 & 10.2747 & 4 & 12833 & 1.61 & 0.26 & 54 & 1 & 143 & 3 & 288 & 86 \\
\hline AY51 & 5.2122 & 10.2747 & 4 & 1100 & 1.16 & 0.51 & 142 & 1 & 44 & 16 & 232 & 77 \\
\hline AY52 & 5.2080 & 10.2680 & 4 & 2236 & 1.34 & 0.11 & 173 & 7 & 44 & 24 & 300 & 79 \\
\hline AY79 & 5.1777 & 10.1833 & 6 & 1109 & 1.23 & 0.79 & 181 & 36 & 9 & 54 & 272 & 4 \\
\hline
\end{tabular}

K-feldspar megacryst granites

Domain I

\begin{tabular}{|c|c|c|c|c|c|c|c|c|c|c|c|c|}
\hline AY17 & 5.2675 & 10.2269 & 4 & 1081 & 1.08 & -0.39 & 33 & 6 & 297 & 84 & 296 & 7 \\
\hline AY18 & 5.2666 & 10.22 & 4 & 658 & 1.13 & 0.07 & 207 & 4 & 117 & 11 & 287 & 79 \\
\hline AY 23 & 5.2569 & 10.2086 & 4 & 1466 & 1.10 & 0.26 & 75 & 35 & 200 & 43 & 322 & 32 \\
\hline AY24 & 5.2605 & 10.2127 & 4 & 1120 & 1.09 & 0.36 & 76 & 55 & 239 & 45 & 322 & 10 \\
\hline AY 25 & 5.2597 & 10.2166 & 4 & 1015 & 1.05 & -0.05 & 145 & 49 & 357 & 40 & 263 & 10 \\
\hline AY26 & 5.2641 & 10.2208 & 4 & 1251 & 1.06 & -0.46 & 210 & 4 & 317 & 76 & 116 & 15 \\
\hline AY 27 & 5.2658 & 10.213 & 4 & 1227 & 1.17 & 0.50 & 105 & 1 & 195 & 12 & 6 & 78 \\
\hline AY 28 & 5.2722 & 10.2244 & 4 & 994 & 1.06 & -0.27 & 81 & 43 & 322 & 34 & 211 & 32 \\
\hline AY29 & 5.3066 & 10.2666 & 4 & 787 & 1.14 & -0.35 & 52 & 18 & 175 & 62 & 309 & 20 \\
\hline AY30 & 5.3022 & 10.2647 & 4 & 671 & 1.07 & 0.27 & 18 & 33 & 227 & 54 & 117 & 14 \\
\hline AY31 & 5.2858 & 10.2483 & 4 & 2725 & 1.15 & -0.16 & 208 & 6 & 93 & 77 & 300 & 13 \\
\hline AY32 & 5.2919 & 10.2602 & 4 & 2784 & 1.19 & -0.17 & 210 & 7 & 86 & 78 & 301 & 10 \\
\hline AY33 & 5.2816 & 10.2444 & 4 & 161 & 1.06 & -0.15 & 234 & 7 & 112 & 75 & 326 & 12 \\
\hline AY34 & 5.2816 & 10.2444 & 4 & 620 & 1.05 & -0.09 & 204 & 6 & 111 & 41 & 301 & 50 \\
\hline AY35 & 5.2813 & 10.2455 & 4 & 802 & 1.06 & -0.33 & 48 & 16 & 142 & 14 & 270 & 69 \\
\hline AY36 & 5.2794 & 10.2394 & 4 & 99 & 1.08 & 0.05 & 56 & 16 & 36 & 28 & 177 & 62 \\
\hline AY37 & 5.2697 & 10.2475 & 4 & 446 & 1.07 & 0.51 & 144 & 5 & 53 & 5 & 281 & 84 \\
\hline AY38 & 5.275 & 10.2308 & 4 & 2413 & 1.07 & -0.02 & 49 & 28 & 181 & 50 & 299 & 24 \\
\hline AY39 & 5.2813 & 10.225 & 4 & 477 & 1.10 & 0.45 & 39 & 7 & 146 & 67 & 306 & 22 \\
\hline AY40 & 5.2741 & 10.2177 & 4 & 512 & 1.10 & 0.39 & 29 & 4 & 126 & 65 & 297 & 25 \\
\hline
\end{tabular}


Table 1. (Continued).

\begin{tabular}{|c|c|c|c|c|c|c|c|c|c|c|c|c|}
\hline \multirow[b]{3}{*}{ Site } & \multirow[b]{3}{*}{ Lat. $N\left(^{\circ}\right)$} & \multirow[b]{3}{*}{ Long. $\mathrm{E}\left({ }^{\circ}\right)$} & \multirow[b]{3}{*}{$\mathrm{N}$} & \multicolumn{3}{|c|}{ Mean AMS parameters } & \multicolumn{6}{|c|}{ Mean eigenvectors } \\
\hline & & & & \multicolumn{2}{|l|}{$\mathrm{Km}\left(10^{-6}\right)$} & \multirow[b]{2}{*}{$T$} & \multicolumn{2}{|c|}{$\mathrm{K}_{1}$} & \multicolumn{2}{|c|}{$\mathrm{K}_{2}$} & \multicolumn{2}{|c|}{$\mathrm{K}_{3}$} \\
\hline & & & & $(\mu \mathrm{SI})$ & $P^{\prime}$ & & $\operatorname{Dec}\left(^{\circ}\right)$ & $\operatorname{Inc}\left({ }^{\circ}\right)$ & $\operatorname{Dec}\left(^{\circ}\right)$ & $\operatorname{Inc}\left({ }^{\circ}\right)$ & $\operatorname{Dec}\left(^{\circ}\right)$ & $\operatorname{Inc}\left({ }^{\circ}\right)$ \\
\hline AY41 & 5.2858 & 10.23 & 4 & 62 & 1.11 & 0.22 & 31 & 5 & 133 & 67 & 299 & 24 \\
\hline AY42 & 5.2922 & 10.24 & 4 & 359 & 1.08 & 0.58 & 31 & 35 & 175 & 50 & 288 & 18 \\
\hline AY58 & 5.308 & 10.3066 & 4 & 1343 & 1.11 & 0.03 & 190 & 51 & 340 & 34 & 79 & 14 \\
\hline AY59 & 5.3105 & 10.3027 & 4 & 2089 & 1.14 & 0.50 & 211 & 62 & 3 & 27 & 101 & 5 \\
\hline AY60 & 5.3058 & 10.303 & 4 & 4527 & 1.16 & 0.23 & 91 & 14 & 283 & 71 & 181 & 11 \\
\hline AY61 & 5.3083 & 10.2961 & 4 & 684 & 1.14 & 0.32 & 2 & 3 & 228 & 86 & 92 & 3 \\
\hline AY62 & 5.3069 & 10.2933 & 6 & 4657 & 1.30 & 0.46 & 185 & 26 & 231 & 56 & 84 & 20 \\
\hline AY63 & 5.3183 & 10.2897 & 4 & 5625 & 1.37 & 0.40 & 65 & 26 & 85 & 35 & 358 & 1 \\
\hline AY64 & 5.3044 & 10.2802 & 4 & 6832 & 1.35 & 0.13 & 217 & 11 & 123 & 21 & 333 & 67 \\
\hline AY65 & 5.3086 & 10.2819 & 4 & 290 & 1.08 & -0.04 & 111 & 1 & 21 & 14 & 212 & 76 \\
\hline AY66 & 5.3005 & 10.2822 & 4 & 527 & 1.05 & 0.31 & 317 & 25 & 66 & 34 & 199 & 45 \\
\hline AY67 & 5.2727 & 10.2655 & 5 & 9469 & 1.38 & 0.36 & 207 & 19 & 112 & 14 & 351 & 67 \\
\hline AY68 & 5.2755 & 10.2636 & 4 & 17295 & 1.33 & 0.38 & 290 & 34 & 159 & 43 & 37 & 26 \\
\hline AY69 & 5.278 & 10.2583 & 5 & 15511 & 1.58 & -0.24 & 301 & 53 & 77 & 25 & 301 & 53 \\
\hline AY70 & 5.2777 & 10.2602 & 4 & 35836 & 1.95 & 0.22 & 29 & 4 & 251 & 84 & 119 & 4 \\
\hline AY71 & 5.2841 & 10.263 & 6 & 18196 & 1.73 & 0.12 & 216 & 10 & 38 & 81 & 306 & 1 \\
\hline AY72 & 5.2913 & 10.2641 & 5 & 662 & 1.07 & 0.44 & 7 & 23 & 98 & 1 & 189 & 67 \\
\hline AY73 & 5.2877 & 10.25 & 4 & 486 & 1.07 & -0.24 & 90 & 62 & 230 & 22 & 327 & 18 \\
\hline AY74 & 5.2608 & 10.2525 & 4 & 4129 & 1.22 & 0.57 & 243 & 52 & 340 & 5 & 74 & 38 \\
\hline AY80 & 5.2602 & 10.2252 & 4 & 598 & 1.07 & 0.62 & 275 & 52 & 12 & 5 & 107 & 33 \\
\hline AY81 & 5.2533 & 10.218 & 4 & 768 & 1.11 & 0.35 & 235 & 77 & 251 & 12 & 55 & 36 \\
\hline \multicolumn{13}{|c|}{ Domain II } \\
\hline AY1 & 5.2447 & 10.2166 & 4 & 120 & 1.06 & -0.50 & 13 & 12 & 104 & 14 & 243 & 14 \\
\hline AY2 & 5.2436 & 10.2227 & 4 & 3104 & 1.18 & 0.20 & 56 & 10 & 166 & 64 & 323 & 30 \\
\hline AY3 & 5.2363 & 10.2133 & 4 & 381 & 1.07 & -0.30 & 18 & 4 & 113 & 43 & 276 & 46 \\
\hline AY4 & 5.2327 & 10.2102 & 4 & 376 & 1.07 & -0.04 & 189 & 1 & 101 & 69 & 278 & 34 \\
\hline AY5 & 5.2283 & 10.213 & 4 & 598 & 1.10 & 0.40 & 196 & 2 & 100 & 69 & 289 & 21 \\
\hline AY6 & 5.2269 & 10.2102 & 4 & 362 & 1.10 & 0.00 & 195 & 17 & 8 & 74 & 105 & 1 \\
\hline AY7 & 5.2258 & 10.2083 & 4 & 153 & 1.04 & 0.12 & 179 & 19 & 291 & 48 & 76 & 36 \\
\hline AY8 & 5.225 & 10.2047 & 4 & 2254 & 1.13 & 0.12 & 207 & 4 & 117 & 11 & 267 & 78 \\
\hline AY9 & 5.2213 & 10.2016 & 4 & 2555 & 1.20 & 0.10 & 189 & 13 & 50 & 74 & 281 & 10 \\
\hline AY10 & 5.2133 & 10.1961 & 4 & 3339 & 1.20 & -0.02 & 193 & 6 & 52 & 83 & 283 & 5 \\
\hline AY11 & 5.2275 & 10.203 & 4 & 2353 & 1.19 & 0.02 & 197 & 8 & 104 & 22 & 305 & 67 \\
\hline AY12 & 5.2355 & 10.1997 & 4 & 5320 & 1.21 & -0.36 & 176 & 26 & 79 & 14 & 324 & 60 \\
\hline AY13 & 5.2336 & 10.1911 & 4 & 4638 & 1.18 & -0.32 & 177 & 23 & 82 & 10 & 328 & 65 \\
\hline AY14 & 5.23 & 10.1977 & 4 & 708 & 1.03 & 0.08 & 226 & 85 & 328 & 13 & 220 & 17 \\
\hline AY15 & 5.2375 & 10.2063 & 4 & 322 & 1.06 & -0.17 & 196 & 6 & 103 & 27 & 301 & 62 \\
\hline AY16 & 5.2402 & 10.2052 & 4 & 1493 & 1.13 & -0.26 & 203 & 4 & 313 & 78 & 112 & 11 \\
\hline AY19 & 5.2208 & 10.1933 & 3 & 946 & 1.07 & -0.75 & 181 & 3 & 274 & 64 & 90 & 26 \\
\hline AY20 & 5.2177 & 10.1925 & 3 & 1412 & 1.03 & -0.18 & 338 & 9 & 69 & 21 & 233 & 69 \\
\hline AY21 & 5.2297 & 10.1872 & 4 & 772 & 1.02 & -0.24 & 173 & 42 & 27 & 51 & 291 & 17 \\
\hline \multicolumn{13}{|c|}{ Domain III } \\
\hline AY75 & 5.2086 & 10.1808 & 5 & 887 & 1.03 & -0.50 & 290 & 34 & 129 & 63 & 36 & 31 \\
\hline AY76 & 5.1986 & 10.1788 & 4 & 561 & 1.04 & -0.22 & 228 & 8 & 121 & 66 & 31 & 24 \\
\hline AY77 & 5.2077 & 10.1883 & 4 & 3370 & 1.05 & -0.16 & 348 & 24 & 145 & 64 & 171 & 81 \\
\hline AY78 & 5.1911 & 10.1997 & 5 & 611 & 1.11 & 0.35 & 263 & 10 & 153 & 4 & 350 & 86 \\
\hline
\end{tabular}

tiny inclusions in silicate minerals (Pignotta and Benn 1999). According to Gregoire et al. (1998), when a granite has ferrimagnetic or ferromagnetic (sensu lato) behaviour (i.e., magnetite-bearing granites), $\mathrm{K}_{3}$ defines the pole of the average flattening plane and $K_{1}$, the elongation direction 
of the shape-preferred orientation of magnetite. Therefore, the foliations and lineations obtained by magnetic methods can be used as indicatives of the mineral fabrics.

The relationship between tensor axes, normalized by means of Jelinek's method (1978, table 1) was studied using: (i) the anisotropy degree $P^{\prime}$ according to Jelinek (1981), which shows the intensity of the preferred orientation of minerals, and (ii) the shape parameter, $\left.T=\left(2 \ln \left(\mathrm{K}_{2} / \mathrm{K}_{3}\right) / \ln \left(\mathrm{K}_{1} / \mathrm{K}_{3}\right)\right)-1\right)$, which varies between -1 (prolate ellipsoids) and +1 (oblate ellipsoids).

Information on magnetic mineralogy is of crucial importance in magnetic studies of rocks (Petrovsky and Kapicka 2006). Standard analytical methods and sensitive thermomagnetic analyses are used to determine temperature dependence of magnetic parameters as basis of determination of magnetic second-order phase transition temperatures. Although limited by several drawbacks, the most serious being thermally-induced transformations of the original minerals, this method provides useful information about the presence of magnetite minerals, and additional knowledge on the prevailing grain size distribution or degree of substitution. According to Tarling and Hrouda (1993), the contribution of magnetic mineralogy to rock susceptibility is very important in magnetic anisotropy investigation because the minerals show different behaviour in different geological situations. One of the methods for the resolution of the rock susceptibility into its ferromagnetic and paramagnetic components is based on the investigation of the temperature variation of susceptibility. The thermomagnetic curves give information about the temperature changes of susceptibility in the initial part of the thermomagnetic curves of the ferromagnetic minerals (Hrouda et al. 1997). Although the susceptibility temperature variation can be used in principle for the susceptibility resolution into ferromagnetic and paramagnetic components, the application must be made with care, because of possible problems concerning the susceptibility $v s$. temperature relationship for the ferromagnetic minerals.

To ground the interpretation of AMS results, it is necessary to know which minerals are carrying the susceptibility and in which proportion (Rochette et al. 1992; Benn et al. 1999). Namely, hysteresis loops were used to estimate the proportion carried by paramagnetic minerals and estimate the type and grain size of the ferromagnetic minerals. Thermomagnetic analyses further allowed to determine the Curie point of the ferromagnetic minerals (following Petrovsky and Kapicka 2006).

Samples were measured for AMS (1) in the laboratory of magnetism at the University Chouaïb Doukkali of El Jadida in Morocco, and (2) in the 'Laboratoire de Géologie-MinéralogiePétrophysique et Tectonique' of the University of Ouagadougou in Burkina-Faso. Thermomagnetic analyses were obtained using a CS2 apparatus coupled to the KLY-3S Kappabridge instrument (Agico, Czech Republic) in the Laboratoire Géosciences Environnement Toulouse (GET; France) and hysteresis analyses were carried out using a Micromag VSM on $1 \mathrm{cc}$ cubes in CEREGE UMR6635 Aix-Marseille Université CNRS Europole de l'Arbois Aix-en-Provence (France).

The raw magnetic data for each of the 88 sites concerning the study area are reported in table 1.

\section{Results}

\subsection{Petrography}

K-feldspar megacryst granites are the main petrographic component of the pluton. They are greyish or leucocratic and pinkish, and coarse- to mediumgrained to fine-grained (average grain size $<3.8$ $\mathrm{mm}$ ). They contain phenocrysts of alkali feldspar (figure $4 \mathrm{~b}, \mathrm{c}, \mathrm{e}, \mathrm{f}$ ) responsible for a noticeable mineral preferred orientation acquired during the magmatic stage or later. In this post-magmatic case, porphyroclasts of feldspar are moulded in a fine-grained matrix, sometimes with quartz ribbons showing evidences of dynamic recrystallization. Other minerals are quartz, plagioclase and variable amount of hornblende, biotite and accessory minerals as zircon, apatite, sphene, epidote and oxides. Myrmekite are generally abundant at the contact between plagioclase and K-feldspar (figure 4b). The textures are granoblastic heterogranular to mylonitic (figure 4h).

Banded gneiss outcrop at Bania and Babouantou. Rocks are dark grey in colour and composed of clinopyroxene, pargasitic and hastingsitic hornblende, biotite and plagioclase. Accessory minerals are zircon, apatite, sphene, allanite and oxides.

Mylonites are found at the northwestern part of the study area (Fondjomekwet and Fotouni). They are greyish, or sometimes leucocratic, banded, finegrained, with quartz, K-feldspar, biotite, plagioclase, garnet, muscovite, cordierite, sillimanite and monazite. Their mineral composition is indicative of a metapelite protolith that underwent mylonitization under mid-pressure amphibolite facies conditions. These mylonites are the one described by Njanko et al. (2010) in the FFMZ. Beside mylonites, Njanko et al. (2010) have described, in the FFMZ, protomylonites on the southeastern border of the Fomopéa granitic pluton. They belong to the pluton body and are medium- to coarse-grained with quartz, K-feldspar, plagioclase and chlorite, corresponding to the deformation of the plutonic rocks in greenschist facies conditions. 

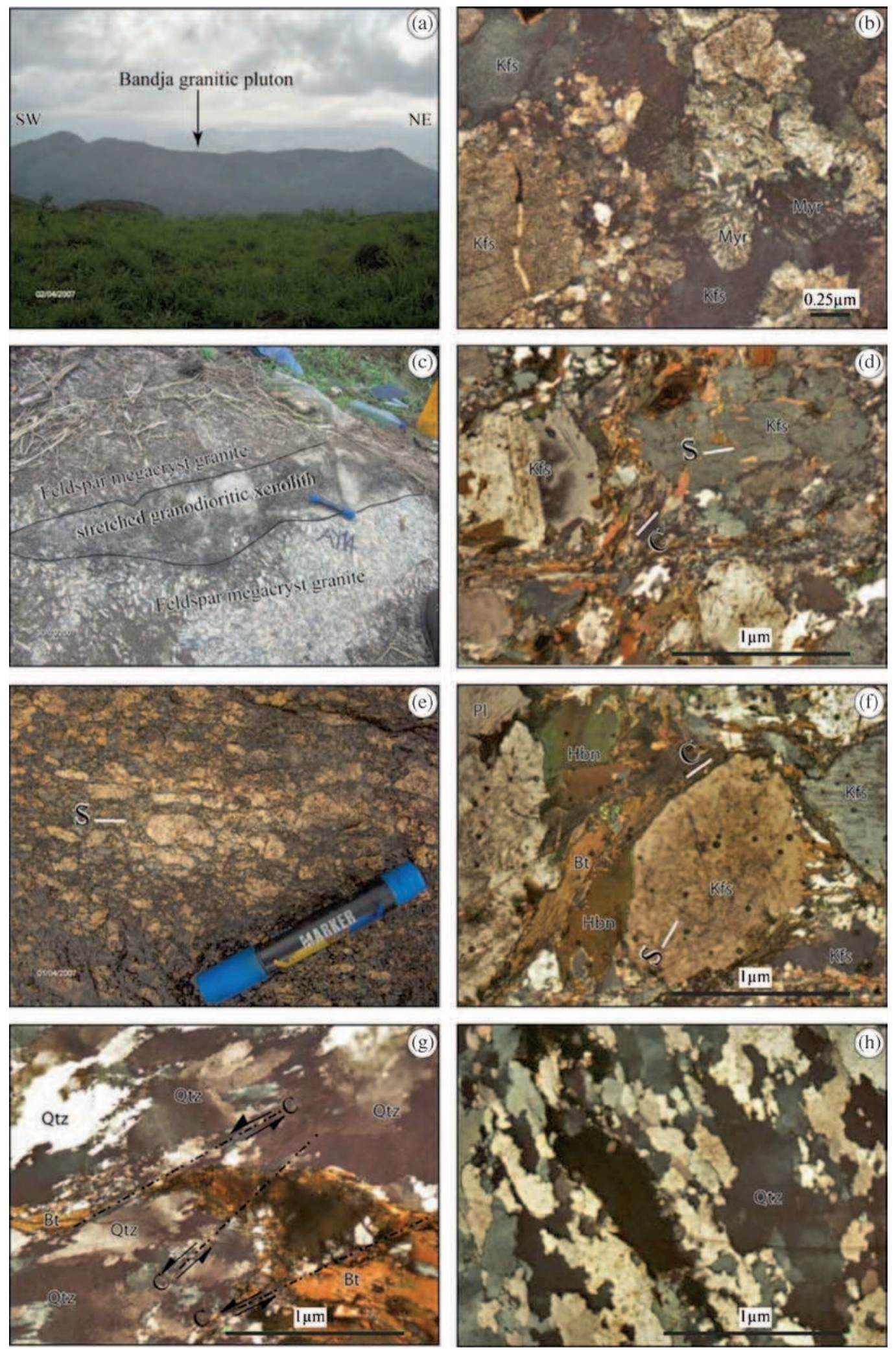

Figure 4. Field photographs and microphotographs (crossed polars) of microstrutures in feldspar megacryst granite: (a) A view of Bandja granitic pluton from Bandja main road; (b) Submagmatic microstructure (AY20), noted (i) the microfault in feldspar filled with quartz and (ii) myrmekite abundance; (c) Feldspar megacryst granite from Bakoven (AY14), noted the stretchted granodioritic xenolith; (d) Incipient solid-state deformation (AY7); (e) Magmatic foliation (S) due to the preferred orientation of K-feldspar megacrysts in granite; (f) S-C sinistral microstructure showing (i) the rotation of feldspar megacryst and (ii) biotite crystal folded in 'S' shape (AY32); (g) Localized sinistral microshear zones (AY7); (h) Mylonitic texture (AY1). Bt: biotite, Hbn: hornblende, Kfs: K-feldspar, Myr: myrmekite, Pl: plagioclase, Qtz: quartz, S: foliation, C: shear planes. 


\subsection{Structures}

\subsubsection{Mesostructural observations}

Structures observed in the field are foliations, S/C structures, stretching lineation and folds. Foliation is observed in banded gneiss, granites and mylonites (figure 5).

In banded gneiss, the foliation is the result of alternation of white (quartz and feldspar rich) and dark (biotite and amphibole rich) layers. It varies between $\mathrm{N} 05^{\circ} \mathrm{E}$ and $\mathrm{N} 19^{\circ} \mathrm{E}$ strikes with low to moderate dips $\left(23^{\circ}-37^{\circ}\right)$ towards the SE or NW and shows best poles at 289/53, 277/66 and 82/62 (figure 5).

In granite, the magmatic foliation is characterized by preferred orientation of minerals as quartz, feldspar, biotite and amphibole. It varies between $\mathrm{N} 16^{\circ} \mathrm{E}$ and $\mathrm{N} 54^{\circ} \mathrm{E}$ strikes with moderate to strong dips towards the SE and shows best poles at 296/23, 313/35, 299/43 and 297/40. This magmatic foliation shows NE-SW strike direction in the northern part of the pluton and NNESSW strike directions in its central part (figure 5). The foliation in banded gneiss seems to deflect to

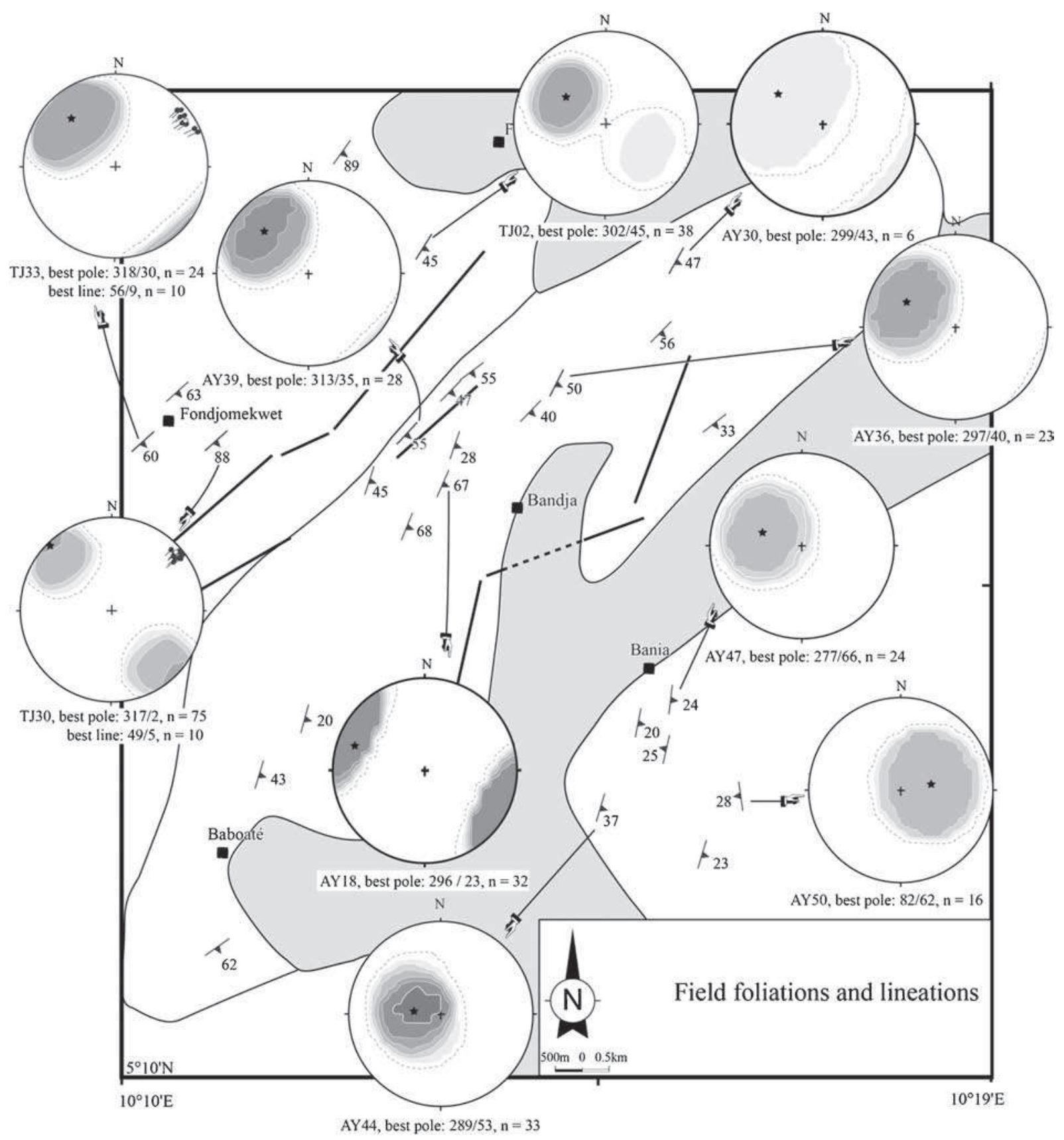

Figure 5. Field foliations and lineations map showing lower hemisphere projection diagrams for foliation poles (contour intervals $=2 \%$ ) and stretching lineation (circle with tail). 
fit the elliptical geometry of the Bandja granitic pluton.

In mylonites, the mylonitic foliation shows homogeneous NE-SW strikes with moderate to very strong dips towards NW or SE. Best poles are at: $302 / 45$ in Fotouni, 318/30 and 317/2 in Fondjomekwet (figure 5).

S/C structures are observed in the FotouniFondjomekwet mylonitic zone and on the western border of the granitic pluton and scattered in the pluton body. In the mylonitic zone, they are consistent with a dextral sense of motion, also confirmed by typical sigma-type porphyroclasts and their crystallization tails. In granite, it is not easy to determine the sense of the motion.

Stretching lineation is observed and measured in the Fotouni-Fondjomekwet mylonitic zone where it is marked by quartz and biotite stretched crystals on the mylonitic foliation planes. It shows NE-SW azimuth with low plunges $\left(<10^{\circ}\right.$; best lines at $49 / 5$ and 56/9; figure 5).

The morphology of the folds points to asymmetric fold shape with SE vergence that have developed long western limbs and thin short eastern limbs with dominant Z-folds on long limbs. Fold axes (best line at 35/6) and mineral stretching lineations are sub-horizontal and strike NE-SW as mylonitic foliation that dips moderately to strongly towards the NW or SE.

\subsubsection{Microstructural observations}

In accordance with modern structural studies in granites (Paterson et al. 1989; Bouchez et al. 1992), detailed microstructural observations have been performed in rocks. Samples from Bandja feldspar megacryst granite show submagmatic to solid-state deformation microstructures. Submagmatic deformation microstructures are marked by (i) feldspar microcracks filled with quartz and (ii) myrmekite crystals (figure 4b) developed on the border of K-feldspar megacrystals. The solid-state deformation microstructures are marked by quartz crystals that have strong undulatory extinction attesting to intracrystalline deformation. Some samples show chessboard texture in quartz (figure $4 \mathrm{~g}, \mathrm{~h}$ ) in which square subgrains with boundaries parallel to both prism and basal planes attest the deformation at high temperature (Blenkinsop 2000). Deformation twins in feldspar, S-C structures observed in granites (figure 4d, f) and mylonites (figure $4 \mathrm{~g}$ ) and kinked biotites are noted. Besides, ductilely deformed feldspar, recrystallized feldspars are also observed. All the above microstructures imply that the granite developed intense deformation in the solid-state and at rather high temperatures.

\subsection{Magnetic mineralogy}

\subsubsection{Hysteresis}

Fifteen representative 1 cc samples (for about $1 \mathrm{~cm}^{3}$ volume) have been measured (table 2 and figure 6 ). The ferromagnetic contribution was calculated by subtracting the high field slope, mostly paramagnetic, to the hysteresis curve that combines both ferromagnetic (sensu lato) and paramagnetic contributions. Hysteresis loop shapes and parameters are typical of magnetite or other spinel oxides. The comparison of high field susceptibility (Khf) to low field susceptibility (Ko), measured on the same sample with the same orientation on

Table 2. Hysteresis parameters for a selection of representative 1 cc samples, together with low susceptibility parameters. High and low field susceptibilities are expressed in volumic $10^{-6}$ units using a fixed density of 2.7. Ms is in Am $/ \mathrm{kg}^{2}$. Model low field susceptibility is derived from $M$ s using theoretical Ms/K ratio for MD magnetite.

\begin{tabular}{|c|c|c|c|c|c|c|c|c|c|c|c|}
\hline Site & $\mathrm{m}$ & Ms & Mrs/Ms & $\mathrm{Bcr} / \mathrm{Bc}$ & Bcr & $\mathrm{Bc}$ & $\begin{array}{l}\text { Ko } \\
(\mu \mathrm{SI})\end{array}$ & Khf & Ko model & \%para & $\begin{array}{l}\% \text { para } \\
\text { model }\end{array}$ \\
\hline AY27 & 1.57 & 37.5 & 0.06 & 7.3 & 47.1 & 6.5 & 1070 & 208 & 849 & 19 & 24 \\
\hline AY35 & 1.58 & 11.6 & 0.13 & 2.4 & 24.0 & 10.0 & 724 & 491 & 690 & 68 & 71 \\
\hline AY59 & 1.50 & 31.3 & 0.03 & 8.9 & 34.8 & 3.9 & 832 & 137 & 672 & 16 & 20 \\
\hline AY61 & 1.26 & 118.3 & 0.09 & 4.3 & 45.0 & 10.4 & 2330 & 83 & 2105 & 4 & 4 \\
\hline AY62 & 1.76 & 168.3 & 0.01 & 9.9 & 11.9 & 1.2 & 4375 & 148 & 3024 & 3 & 5 \\
\hline AY63 & 1.35 & 748.3 & 0.03 & 4.7 & 12.1 & 2.6 & 23019 & 131 & 12918 & 1 & 1 \\
\hline AY70 & 1.36 & 626 & 0.06 & 2.6 & 7.5 & 2.9 & 23552 & 700 & 11397 & 3 & 6 \\
\hline AY71 & 1.51 & 522 & 0.01 & 7.0 & 8.4 & 1.2 & 14722 & 396 & 9317 & 3 & 4 \\
\hline AY73 & 1.49 & 528 & 0.02 & 12.1 & 20.6 & 1.7 & 12572 & 232 & 9255 & 2 & 3 \\
\hline AY75 & 1.44 & 23.5 & 0.25 & 2.6 & 73.0 & 28.0 & 860 & 468 & 869 & 54 & 54 \\
\hline AY76 & 1.63 & 2.3 & 0.08 & 2.7 & 29.0 & 10.8 & 556 & 521 & 560 & 94 & 93 \\
\hline AY77 & 1.44 & 134.4 & 0.02 & 8.1 & 23.5 & 2.9 & 3000 & 254 & 2551 & 8 & 10 \\
\hline AY78 & 1.46 & 47.9 & 0.04 & 7.9 & 38.6 & 4.9 & 1172 & 239 & 1058 & 20 & 23 \\
\hline AY79 & 1.57 & 22.9 & 0.17 & 5.0 & 93.0 & 18.6 & 944 & 447 & 838 & 47 & 53 \\
\hline AY80 & 1.53 & 13.4 & 0.04 & 7.7 & 46.0 & 6.0 & 496 & 308 & 537 & 62 & 57 \\
\hline
\end{tabular}




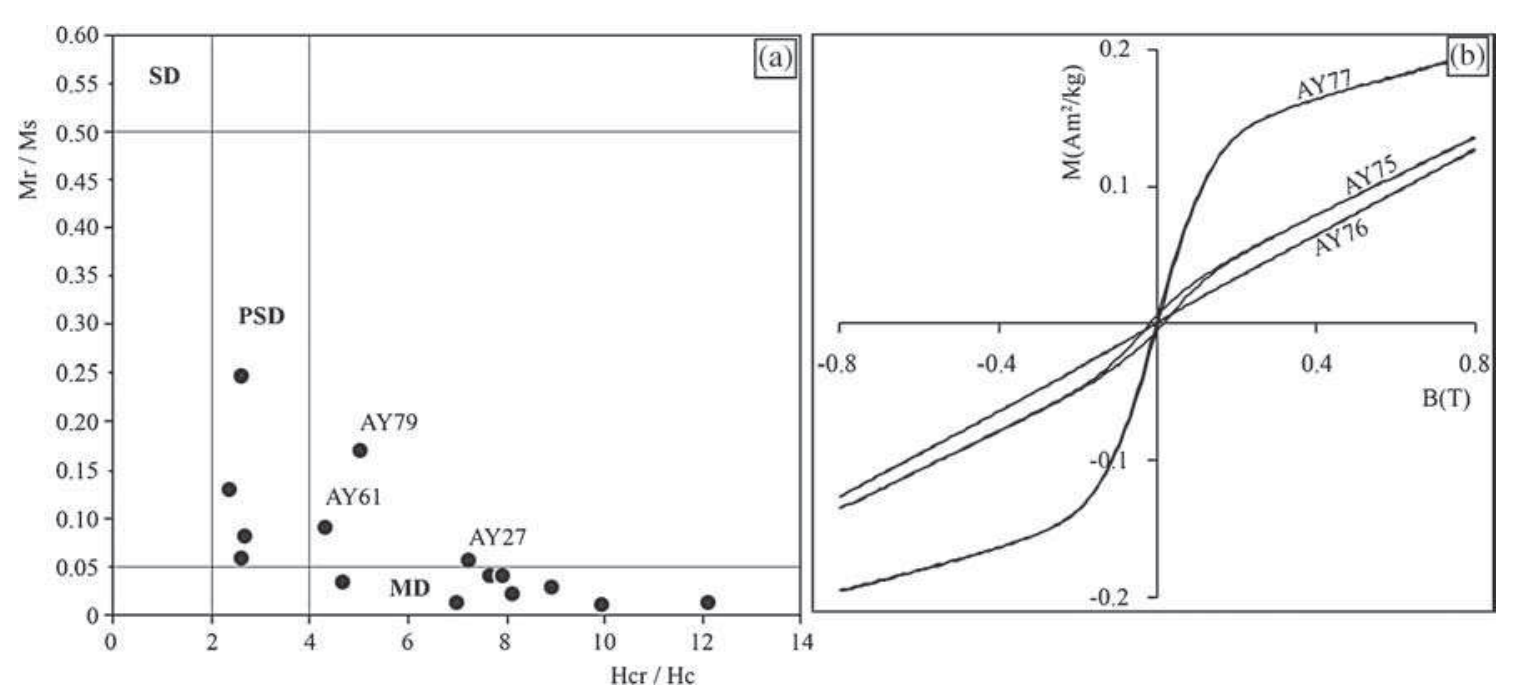

Figure 6. (a) Mrs/Ms vs. Hcr/Hc (hysteresis ratios, Day et al. 1977) diagram of representative samples in K-feldspar megacryst granite, with boundaries of single domain (SD), pseudo-single-domain (PSD) and multi-domain (MD) after Day et al. (1977) and Dunlop (1986). (b) Example of hysteresis loops for samples with paramagnetic (AY76), PSD (AY75) and MD (AY77) behaviour.

the Kappabridge, allows to quantify the relative contribution of paramagnetic minerals to Ko. Alternatively, to overcome the calibration problem between VSM and Kappabridge, we calculate a model Ko based on saturation magnetization (Ms) and Khf following Benn et al. (1999). Both methods lead to similar paramagnetic relative contribution. This contribution varies from 47 to $94 \%$ for Ko $<1000 \mu \mathrm{SI}$, except one sample, AY59, with minor paramagnetic contribution. Still, the ferromagnetic contribution is significant in all samples, except AY76, for which AMS must be entirely carried by iron-bearing silicates. For the other samples, as the anisotropy of magnetite may be much stronger than the one of silicates, it is still likely that AMS is carried by magnetite even if paramagnetic contribution to $\mathrm{Ko}$ is dominant. For samples with Ko > $1000 \mu \mathrm{SI}$, the paramagnetic contribution is minor (up to $20 \%$ on two samples) to negligible. The loop parameters reflect the state of the magnetic domains in magnetite. A plot of the saturation ratio (Mrs/Ms; Mrs is the remanence at saturation and Ms the magnetization at saturation) vs. the hysteresis ratio $(\mathrm{Bcr} / \mathrm{Bc}$ where $\mathrm{Bcr}$ is the remanent coercive force and $\mathrm{Bc}$ the coercive force), or Day's diagram (Day et al. 1977; figure 6a), provides an indication of the size of magnetite grains. Our specimens fall into the PSD (pseudosingle domain) and MD (multi-domain) fields. Once transposed into grain sizes, this indicates that magnetite ranges between 0.1 (PSD) and $>1.0 \mu \mathrm{m}$ (MD). Samples AY27, AY79 and AY61 likely point towards the mixture of hematite and magnetite contribution to remanence. However, the contribution of hematite to susceptibility in these samples must be negligible based on the low specific susceptibility of hematite compared to magnetite.

Progressively, samples were heated up to $700^{\circ} \mathrm{C}$ and cooled to room temperature. Thermomagnetic curves of high susceptibility samples (figure 7) have quite similar shapes, suggesting a similar type of magnetic mineralogy for all parts of the intrusion. Most curves show a significantly higher susceptibility on cooling (not for samples AY10 and AY67 in figure 7a and b), indicative of neoformation of magnetic minerals starting around $300^{\circ}-400^{\circ} \mathrm{C}$ (probably maghemite converted to hematite). They all show a Curie point around $580^{\circ} \mathrm{C}$ with a sharp decrease in susceptibility in all the heating curves, corresponding to the Curie temperature of pure magnetite. The remaining susceptibility above $600^{\circ} \mathrm{C}$ is likely a combination of paramagnetic contribution and residual magnetite signal due to the use of a too large sample mass resulting in part of the sample being cooler than temperature probe. Therefore, it is confirmed that pure magnetite is the main carrier in our high susceptibility samples.

\subsection{AMS data}

AMS analysis gives well-defined magnetic fabrics for all sites in Bandja magmatic pluton and its country rocks (banded gneiss) as well as in mylonites (table 1; figure 8).

\subsubsection{Magnetic susceptibility}

The bulk magnetic susceptibility magnitude (Km) varies from 51 to $35836 \mu \mathrm{SI}$ (table 1; figure 9a) 

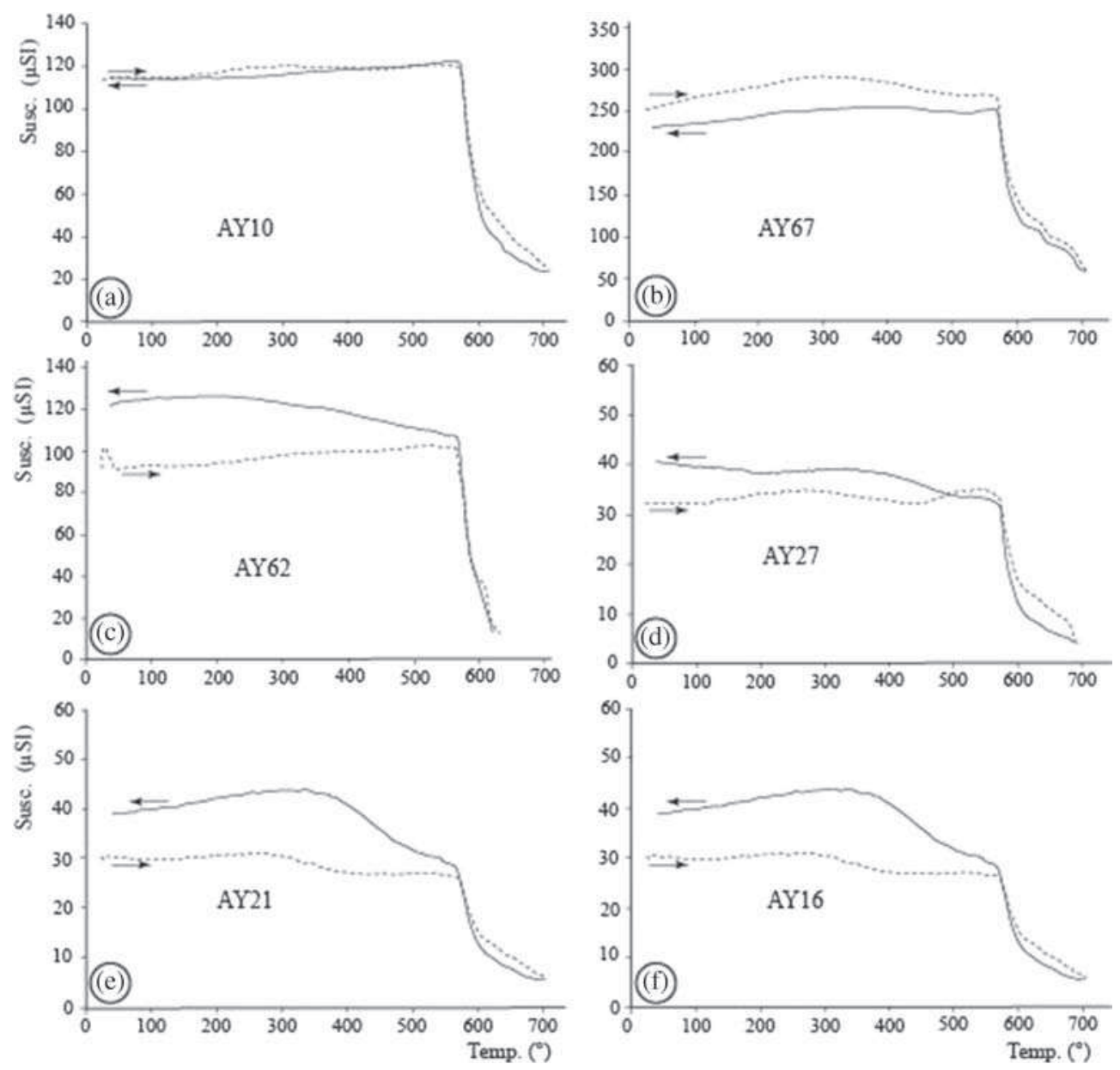

Figure 7. K-T curves (susceptibility vs. temperature) for representative samples (AY10, AY67, AY62, AY27, AY21, AY16).

suggesting, in the study area, the presence of both (i) dominant ferromagnetic behaviour sensu lato (Km $>500 \mu \mathrm{SI}$ ) dominated by the signal of magnetite that represents $72 \%$ of sites and (ii) dominant paramagnetic behaviour $(\mathrm{Km}<500 \mu \mathrm{SI})$ probably dominated by the signal of iron-bearing silicates (Rochette 1987; Bouchez 2000) that represents $28 \%$ of the sites. Km values range from 62 to 35836 $\mu \mathrm{SI}$ in feldspar megacryst granites, indicating $79 \%$ of sites with ferromagnetic behaviour and $21 \%$ of sites with paramagnetic behaviour (figure 9b). The lowest value belongs to site AY41 situated at the western border of the pluton in contact with the mylonites and the highest value belongs to site AY70 nearby the NNE-SSW fracture in the northeastern part of the pluton. In banded amphibole gneiss, $\mathrm{Km}$ varies from 119 to $22463 \mu \mathrm{SI}$. Km values range from 51 to $13131 \mu \mathrm{SI}$ in mylonites, indicating $50 \%$ of sites with ferromagnetic behaviour.

In spite of the fact that fresh samples were obtained in the fields, both paramagnetic and ferromagnetic behaviours are identified in the same petrographic unit and sometimes in the same site, indicating an uneven distribution of magnetite.
There is no particular organization of both behaviours in the granitic pluton.

\subsubsection{Anisotropy degree}

The anisotropy degree $P^{\prime}$ varies from 1.02 to 1.95 for all sampled sites (table 1; figure 10a). In granite, $P^{\prime}$ varies from 1.02 to 1.95 . The very high values of $P^{\prime}$ are located in the northeastern part of the pluton. In mylonites, $P^{\prime}$ varies from 1.06 to 1.65. The site TJ3, that shows the very low value of $\mathrm{Km}(53 \mu \mathrm{SI})$ also shows low value of $P^{\prime}(1.14)$. In banded gneiss, $P^{\prime}$ varies from 1.09 to 1.78 . The kink in $P^{\prime}$ vs. Km plot (figure 10c) confirms that the paramagnetic contribution becomes important below $\mathrm{Km}=1000 \mu \mathrm{SI}$, with $P^{\prime}$ around 1.1, following Rochette et al. (1992). The continuous increase of $P^{\prime} v s . \mathrm{Km}$ for $\mathrm{Km} \gg 1000 \mu \mathrm{SI}$ may indicate that anisotropy of magnetite is enhanced by interaction (Gregoire et al. 1998).

$P^{\prime}$ values lower than 1.15 represents $73 \%$ of sites in feldspar megacryst granites, $20 \%$ of sites in banded gneiss and $53 \%$ of sites in mylonites (figure 10b). According to Rochette et al. (1992) 


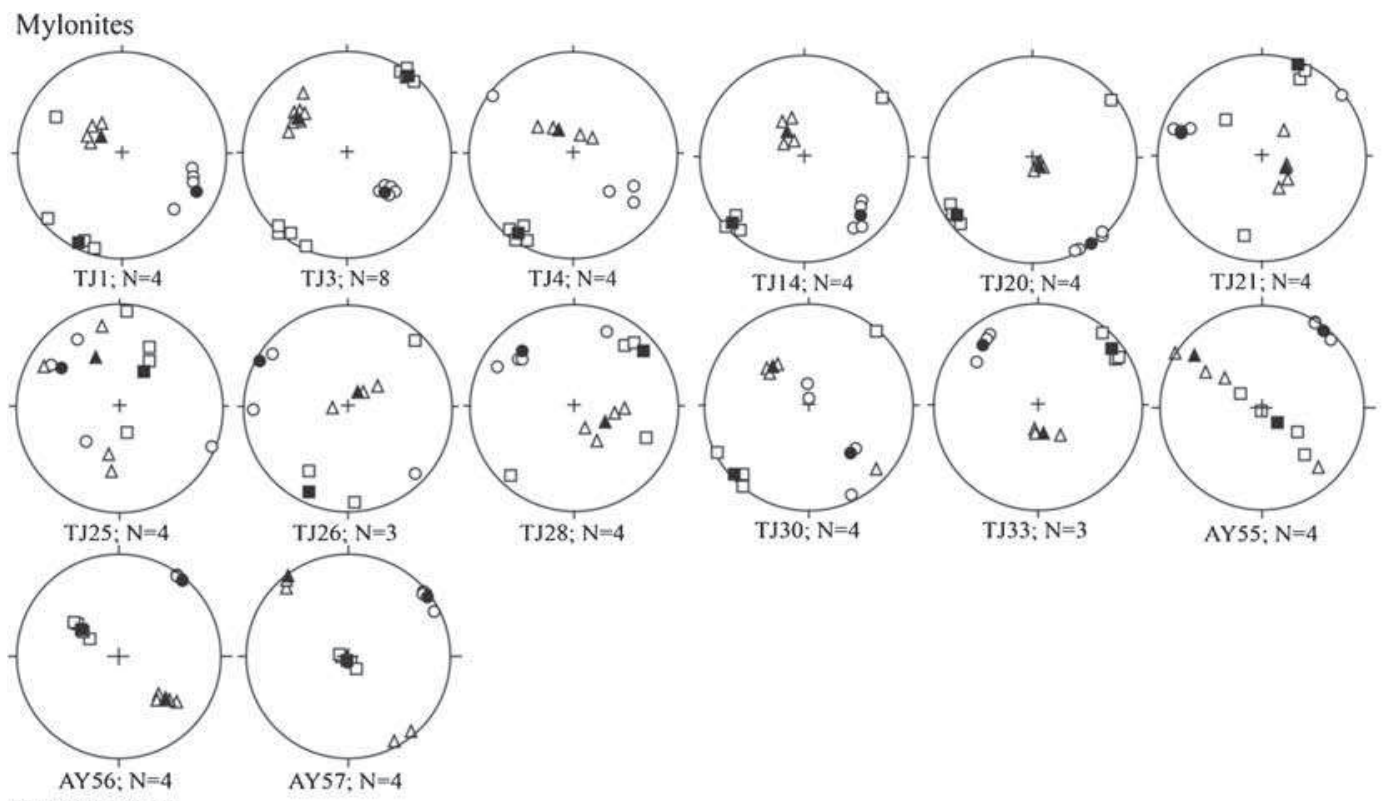

Banded gneiss

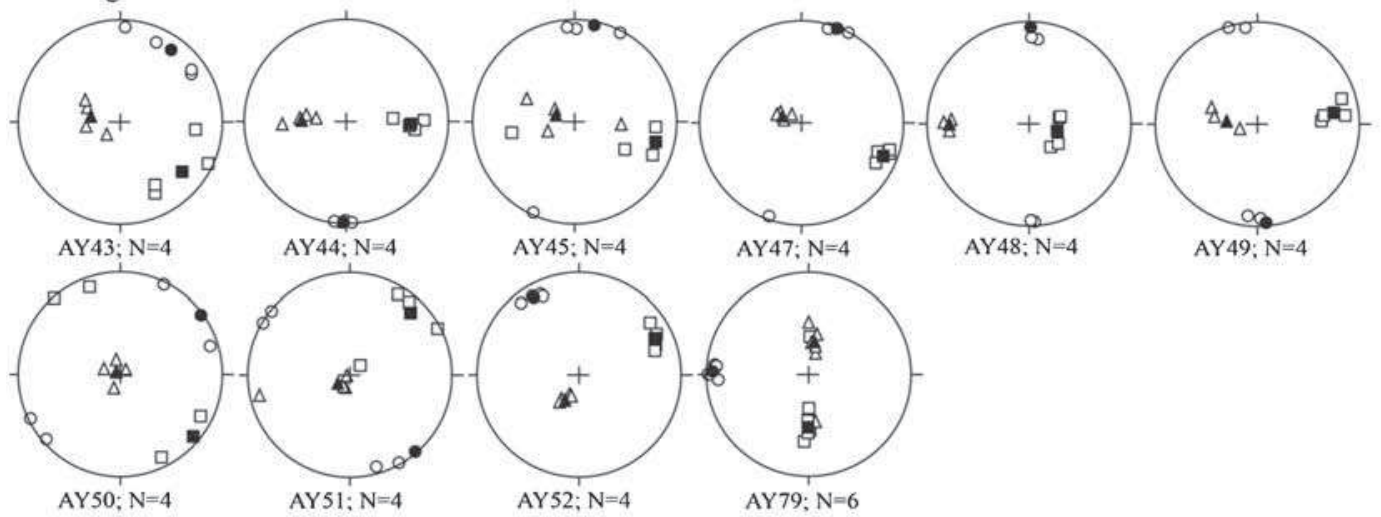

K-feldspar megacryst granites

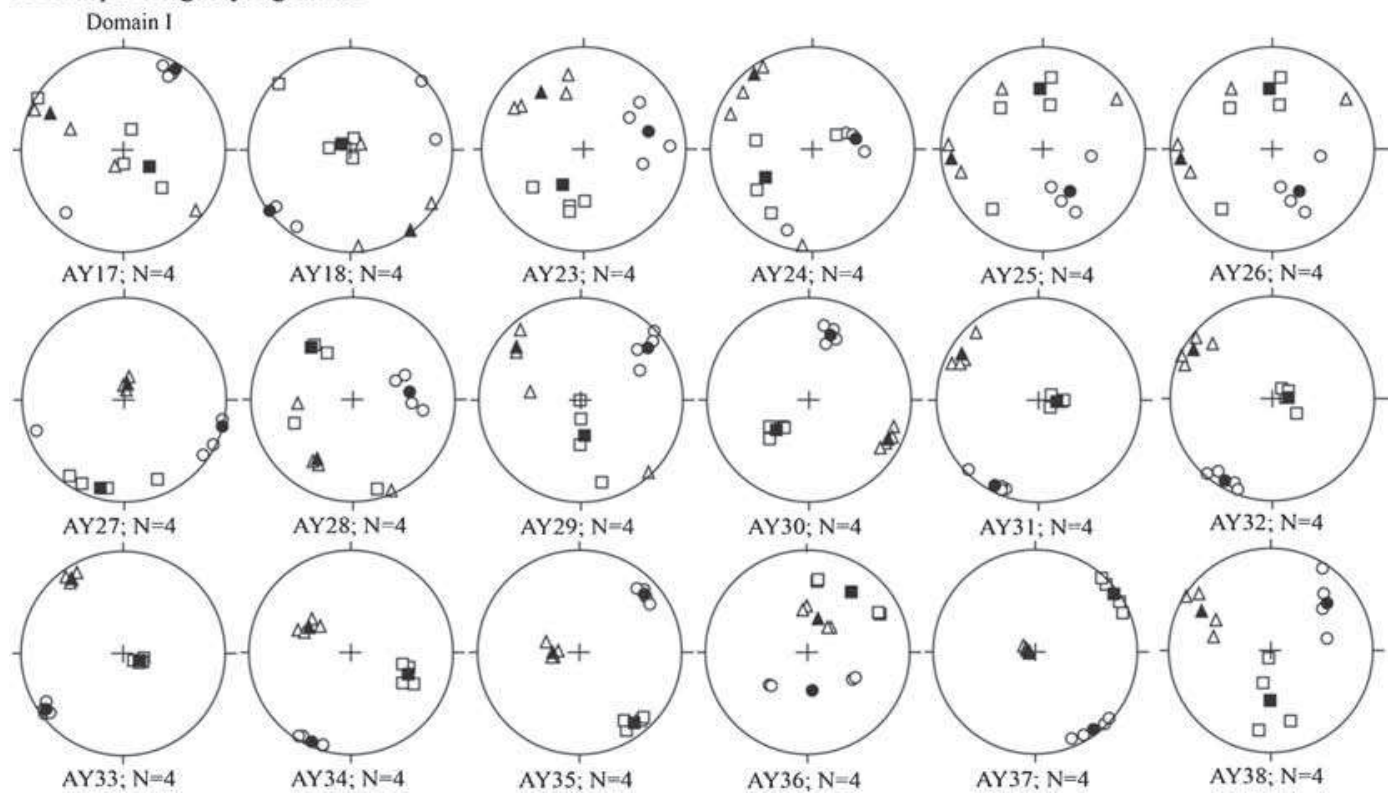

Figure 8. Projection diagrams (lower hemisphere) for AMS data; box represents $K_{\max }$, triangle represents $\mathrm{K}_{\text {int }}$ and circle represents $K_{\min }$; full symbols (box, triangle and circle) represent the averages. 

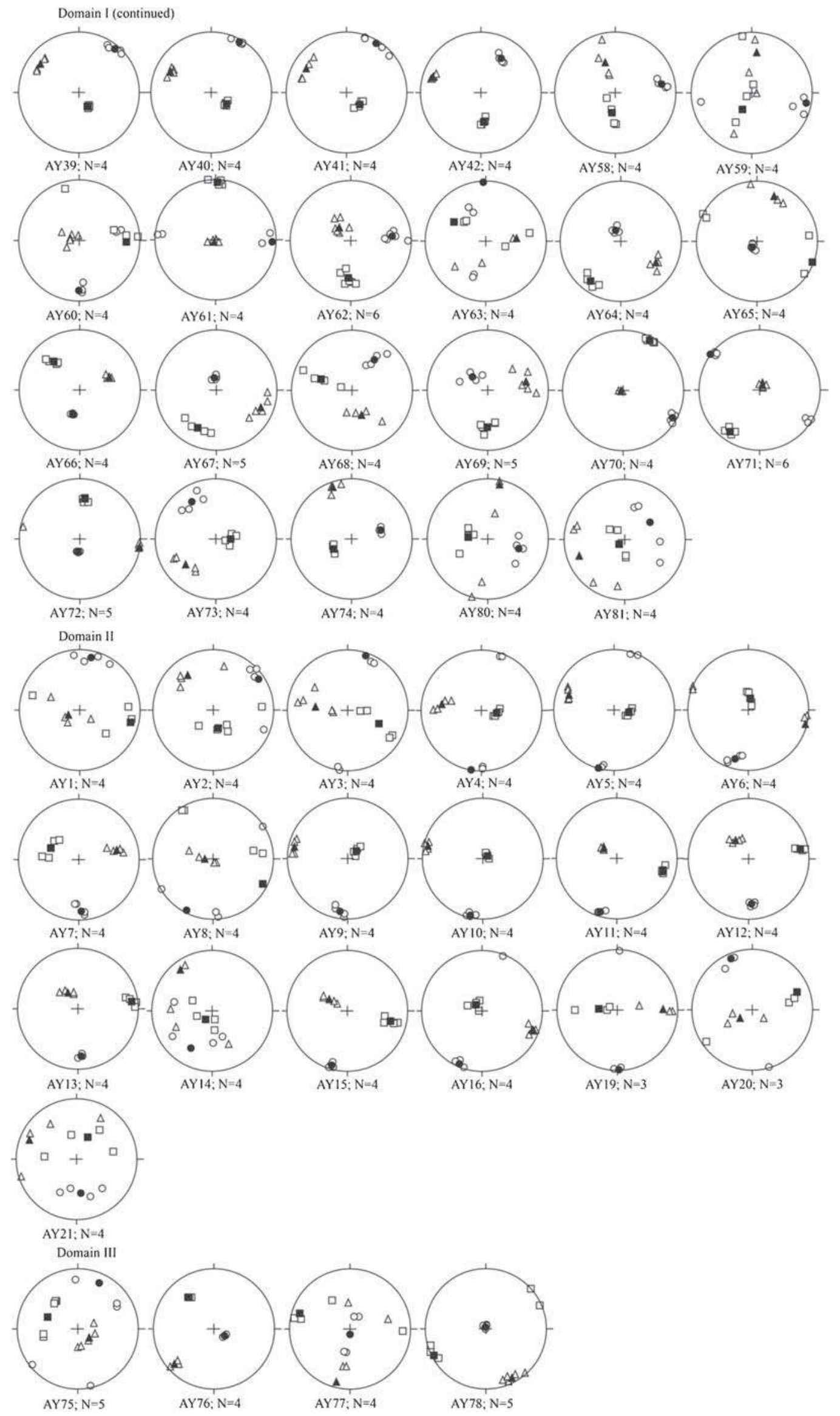

Figure 8. (Continued.) 


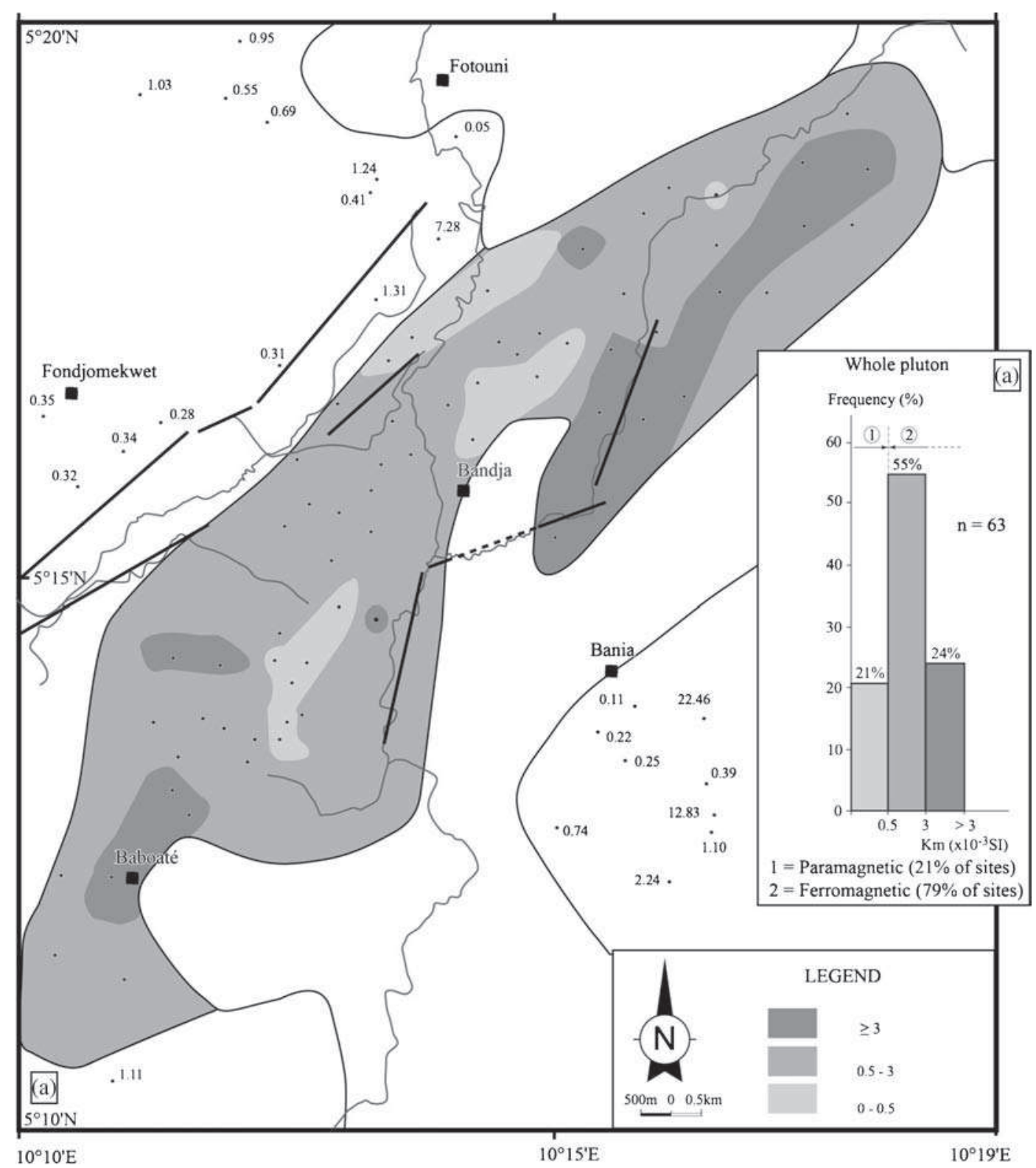

Figure 9. (a) Contour map of the magnetic susceptibility ( $\mathrm{Km}$ in $\mu \mathrm{SI}$ unit) of the Bandja granitic pluton and (b) susceptibility histograms.

and Bouchez (1997, 2000), $P^{\prime}$ values lower than 1.15 may correspond to paramagnetic dominant rocks (also characterized by Km values below 1000 $\mu \mathrm{SI})$, although ferromagnetic dominant rocks may also show low values due to low preferred orientation of magnetite grains.

The sites AY70 and AY71 that show the highest values of $\mathrm{Km}$ also show the highest values of $P^{\prime}$ and are concentrated along a fracture at the northeastern part of the pluton. In all petrographic units, the site that shows the highest value of $\mathrm{Km}$ also shows the highest value of $P^{\prime}$, but sites that show the lowest value of $\mathrm{Km}$ do not show the lowest value of $P^{\prime}$.

\subsubsection{Shape parameter $(T)$}

The Jelinek's (1981) shape parameter (T) of the AMS ellipsoid is presented in table 1 and figure 11. About $12 \%$ of sites show oblate-shape ellipsoid, while $5 \%$ of sites show prolate-shape ellipsoid and $83 \%$ of sites a triaxial-shape ellipsoid. In mylonites, $\mathrm{T}$ indicates $7 \%$ of sites with an oblate-shape ellipsoid, $13 \%$ of sites with a prolate-shape ellipsoid and $80 \%$ of sites with a triaxial-shape ellipsoid. In feldspar megacryst granites, $\mathrm{T}$ indicates $8 \%, 2 \%$ and $90 \%$, respectively for oblate-shape, prolateshape and triaxial-shape ellipsoids and in banded gneiss, T indicates $20 \%$ of sites with oblate-shape 


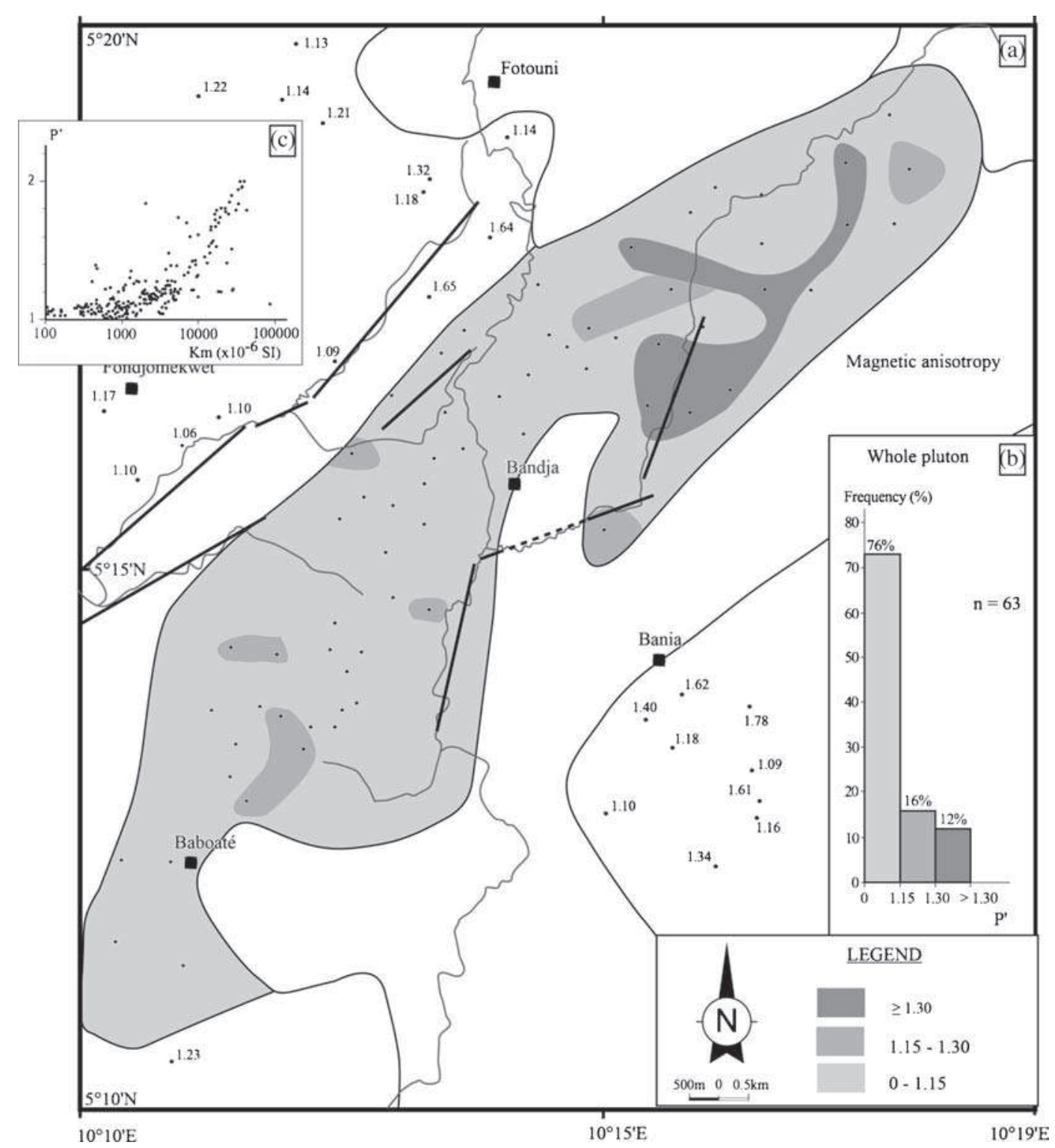

Figure 10. (a) Contour map of the anisotropy degree $\left(P^{\prime}\right)$ of the Bandja granitic pluton and (b) anisotropy degree histogram; and (c) $P^{\prime}$ vs. Km semi-log diagram.

ellipsoid and $80 \%$ of sites with triaxial-shape ellipsoid. The obtained $\mathrm{T}$ parameter correlates well with the AMS projection diagrams. It indicates either $K_{1}$ as axis of $K_{2}$ and $K_{3}$ in a prolate-shape ellipsoid, or $K_{3}$ as axis of $K_{1}$ and $K_{2}$ in an oblateshape ellipsoid, or the grouping together of axis $\mathrm{K}_{1}$, $\mathrm{K}_{2}$ or $\mathrm{K}_{3}$ in a triaxial-shape ellipsoid.

\subsubsection{Magnetic foliations}

$70 \%$ of sites in banded gneiss show magnetic foliation dips between $0^{\circ}$ and $30^{\circ}, 10 \%$ between $30^{\circ}$ and $60^{\circ}$ and $20 \%$ between $60^{\circ}$ and $90^{\circ}$.

General orientations of magnetic foliations in the Bandja feldspar megacryst granite allow to distinguish three different domains (figure 12) called domain I in the northeastern part of the pluton, domain II in its central part and domain III in its southern part. $24 \%$ of sites show magnetic foliation dips between $0^{\circ}$ and $30^{\circ}, 24 \%$ between $30^{\circ}$ and $60^{\circ}$ and $52 \%$ between $60^{\circ}$ and $90^{\circ}$. Domain I shows magnetic foliation projection diagrams striking NE-SW with a best pole at 295/34 and domain II shows magnetic foliation projection diagrams striking NNE-SSW with a best pole at 283/33, while domain III shows a NW-SE striking direction with best pole at $35 / 59$.

In mylonites, azimuths and plunges of magnetic foliations are well organized in NE-SW strike and NW or SE dipping direction with moderate to very high values. The best pole is at $129 / 6$. $79 \%$ of sites show magnetic foliation dips between $60^{\circ}$ and $90^{\circ}$, while $21 \%$ of sites show dips between $30^{\circ}$ and $60^{\circ}$. 

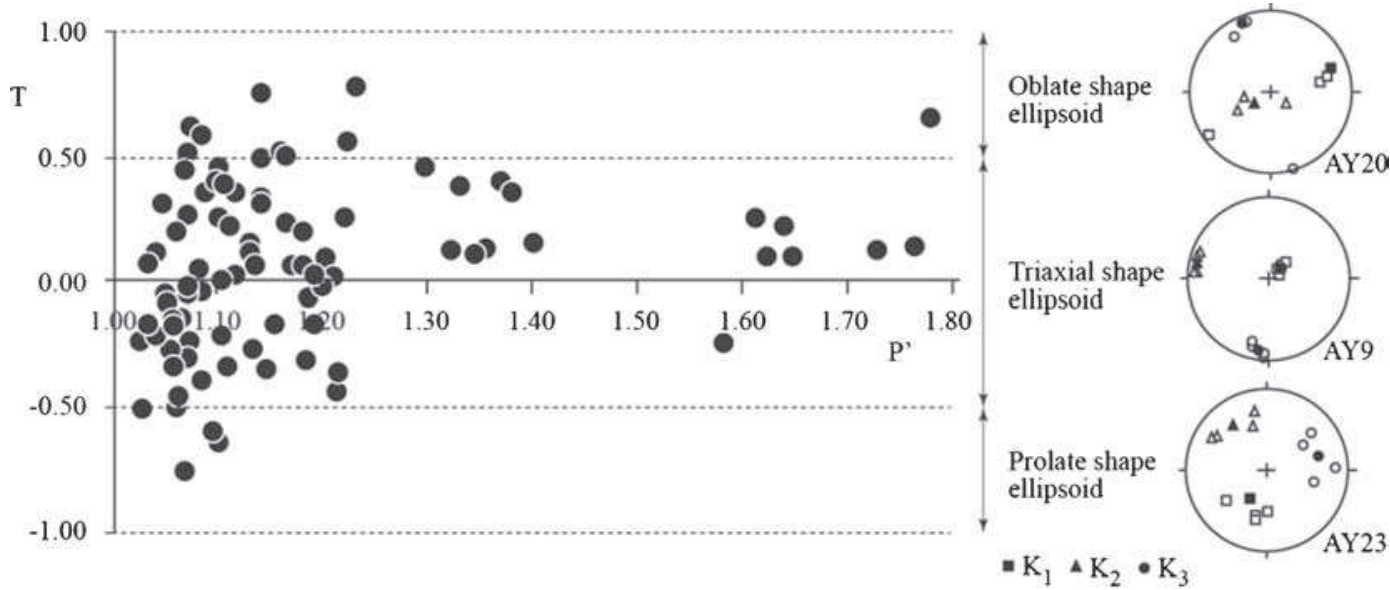

Figure 11. T vs. $P^{\prime}$ diagram.

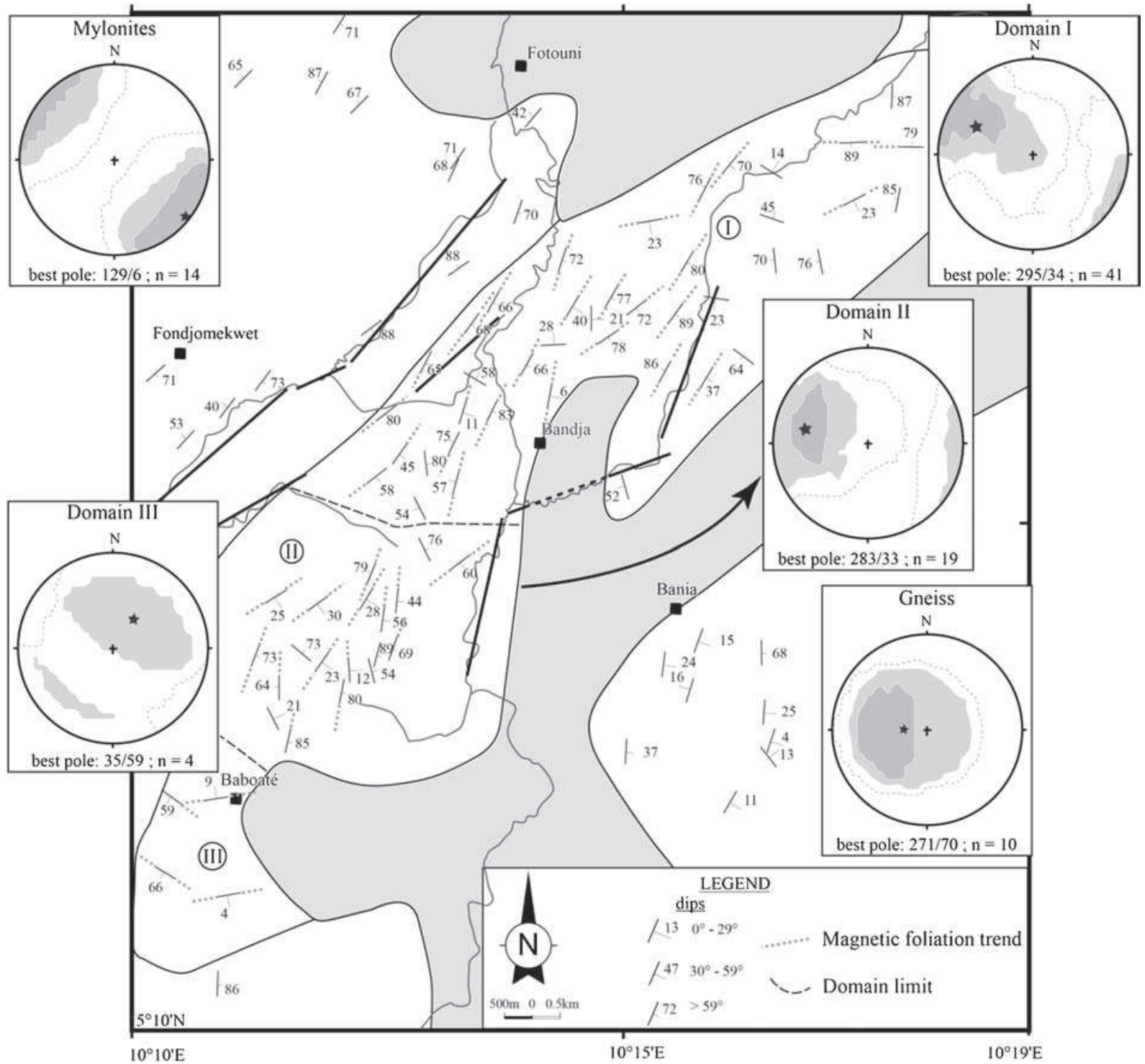

Figure 12. Magnetic foliation map and projection diagrams for foliation poles (lower hemisphere, contour intervals $=2 \%$ ). 


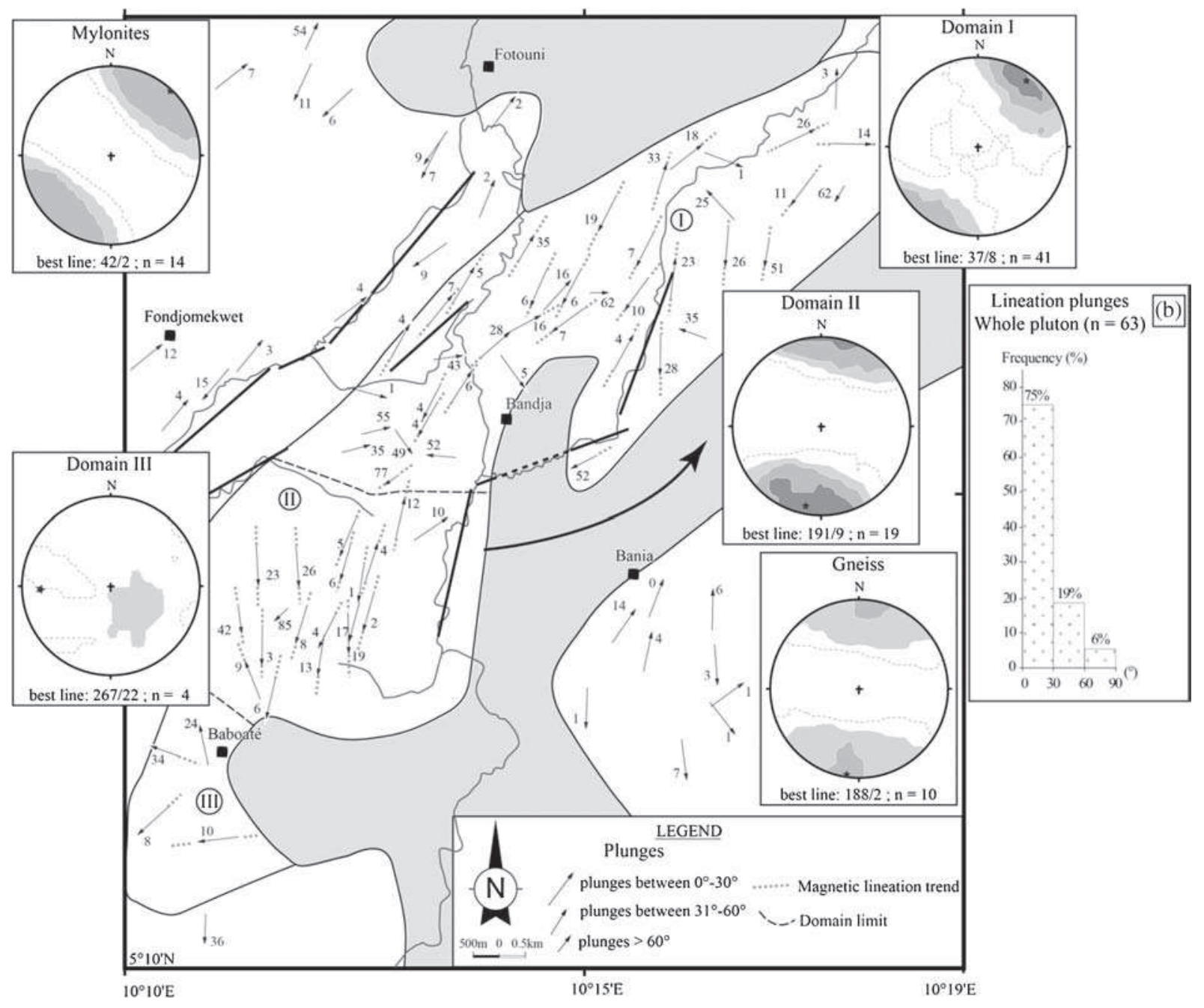

Figure 13. (a) Magnetic lineation map and projection diagrams of $\mathrm{K}_{1}$ AMS parameter (lower hemisphere, contour intervals $=2 \%$ ) and (b) lineation plunges histogram.

\subsubsection{Magnetic lineations}

In banded gneiss and mylonites, magnetic lineations indicate very homogeneous low plunges (90\% and $87 \%$ of sites respectively) with moderate plunges $\left(30^{\circ}-60^{\circ}\right)$, poorly represented $(10 \%$ and $13 \%$, respectively).

In feldspar megacryst granite, $\mathrm{K}_{1}$ presents mostly low plunges $\left(0^{\circ}-30^{\circ}\right.$ for $75 \%$ of sampled sites; figure 13). Moderate plunges represent $20 \%$ of sites, while strong plunges $\left(60^{\circ}-90^{\circ}\right)$ represent $5 \%$ of sites. Magnetic lineations show different behaviours in the three previous domains as magnetic foliation. Domain I shows NE-SW trending magnetic lineations (best line at $37 / 8$ ), while domain II shows N-S (best line at 191/9) trending magnetic lineations and domain III, E-W trending magnetic lineations (best line at 267/22). These trending magnetic lineations point to an S-form trail as magnetic foliation trends.

\section{Interpretation}

\subsection{Structures and microstructures}

Figure 5 indicates magmatic foliation plane strikes varying from the northern to the southern part of the pluton, with moderate to strong dips towards SE. The Bandja feldspar megacryst granite shows weakly deformed to protomylonitic microstructures. Thin sections exhibit megacrysts surrounded by anhedral aggregates of quartz. However, feldspar megacryst microcracks filled with quartz and/or feldspar are likely related to the submagmatic stage and are indicative of melt migration during deformation (Bouchez et al. 1992). Microstructural observations point to the development of the pluton in subsolidus conditions and during a continuum from high to low-temperature conditions. Quartz crystals have strong undulatory extinction with chess-board texture in which 
square subgrains with boundaries parallel to both prism and basal planes and stepped grain boundaries attest the deformation at high temperature (Mainprice et al. 1986). Feldspars show deformation twins indicating that they underwent deformation and recrystallization above $450^{\circ}-$ $500^{\circ} \mathrm{C}$ (Simpson 1985; McCaffrey et al. 1999) and kinked biotites are noted. Myrmekite, which has been inferred as a deformation induced texture (Simpson and Wintsch 1989) and microcline twinning in K-feldspar (Vernon 2000) are also present in granite. S-C structures in the whole pluton witness either dextral, or sinistral transcurrent tectonics that occur in granite or along the northwestern border of the pluton. It is not really possible to dissociate submagmatic to solid-state deformation in the whole pluton and all samples seem to illustrate solid state or mylonitic deformations as: crystal plastic deformation/recrystallization of feldspar, myrmekite, S-C structures and crystal plastic deformation of quartz, from ribbons of equant polygonal grains to dynamically recrystallized grains. A continuous deformation from submagmatic to solid-state and mylonitic deformation is recorded in the Bandja granitic pluton.

Njanko et al. (2010) in the neighbouring area of the Bandja granitic pluton described three phases of deformation: a $D_{1}$ phase responsible of the emplacement of biotite hornblende granite (BHG) magma with NNE-SSW stretching direction that reflect the tectonic strain at that time; a N-S sinistral $\mathrm{D}_{2}$ phase which correspond to the emplacement of the biotite monzogranite $(\mathrm{BmG})$ and a younger dextral $\mathrm{D}_{3}$ phase linked to the functioning of Fotouni-Fondjomekwet Mylonitic Zone (FFMZ), that is the mylonitic zone of the northwestern border of the Bandja granitic pluton.

\subsection{Magnetic data and emplacement of granite}

According to the thermomagnetic analysis, $\mathrm{K}-\mathrm{T}$ curves indicate the presence of magnetite as main susceptibility carrier event if certain low susceptibility samples reveal the paramagnetic component. The predominance of magnetite in samples allows to envisage that the high ferromagnetic behaviour of the granitic unit is closely linked to the presence of magnetite MD in rocks. Sites that show very high magnitude of magnetic susceptibility, also show very high values of the anisotropy degree $\left(P^{\prime}>1.1\right)$. On the other hand, sites with very low magnitude of magnetic susceptibility, do not always present low values of the anisotropy degree. This indicates that the $P^{\prime}$ parameter (usually the quantitative strain intensity indicator) is also influenced by the presence of magnetite in the form of PSD or MD grains in rocks than by the strain itself. This is supported by the semi-logarithmic diagram of the magnetic susceptibility $\mathrm{Km}$ vs. anisotropy degree $P^{\prime}$ (figure 10c), where samples show a hyperbola plot. According to Archanjo et al. (1994), $P^{\prime}$ depends weakly on $\mathrm{Km}$ occasionally, suggesting that rock-composition controls $P^{\prime}$.

Magnetic fabric axes are parallel to the mineral fabric axes and these axes recorded the strain (flattening plane) to which the magma was subjected after its complete crystallization (high-temperature solid-state microstructures). The magnetic foliation and lineation in the three domains of the granitic pluton show different orientations resulting in a sigmoidal path. According to Njanko et al. (2010), the sigmoidal trajectories of magnetic lineation observed in biotite monzogranite of the Fomopéa granitic pluton correspond to a sinistral sense of motion linked to the $D_{2}$ phase of deformation recorded in this neighbouring area. This sinistral $\mathrm{D}_{2}$ event predates the dextral $\mathrm{D}_{3}$ phase recorded in the FFMZ.

\subsection{Discussion on age and geodynamic implication}

The geological history of the Bandja granitic pluton should take into account: (i) different ages obtained by Nguiessi Tchakam et al. (1997), (ii) the available Pan-African ages and the evolution of the Pan-African belt in Cameroon. According to Njiékak et al. (2008), structural and geochronological data from the Batié pluton (BP), in the continuity north of the Bandja granitic pluton, the migmatitic complex of Foumbot (MCF), and the Bangoua metagranitoid complex (BMC) are provided to put constraints on the tectonics of the $\mathrm{N} 30^{\circ} \mathrm{E}$ strike segment of the belt. BMC is dated $638 \pm 2 \mathrm{Ma}$ (U-Pb age on zircon) and the $\mathrm{BP}$ is dated $602 \pm 1.4 \mathrm{Ma}$ (U-Pb age on zircon). Tagné Kamga (2003) dates the Ngondo plutonic complex (also emplaced along $\mathrm{N} 30^{\circ} \mathrm{E}$ strike shear zone) at around $600 \mathrm{Ma}$. These plutons are emplaced during the Neoproterozoïc $D_{2}$ Pan-African event. In the same order, Kwékam et al. (2010) determined, on the Fomopéa granitic pluton, ages: 622-613 Ma for the biotite hornblende granitoid corresponding to $\mathrm{D}_{1}$ Pan-African event (Njanko et al. 2010); 613$590 \mathrm{Ma}$ for the biotite granitoid and corresponding to the $\mathrm{D}_{2}$ Pan-African event (Njanko et al. 2010). The Rb-Sr ages obtained for the Bandja granites $(557 \pm 18 \mathrm{Ma})$ are strikingly younger than the $\mathrm{U}-\mathrm{Pb}$ ages obtained on neighbouring plutons and seem to correspond to the noticeable perturbation of the $\mathrm{Rb}-\mathrm{Sr}$ isotopic system, hence the 572 $\pm 48 \mathrm{Ma}$ age obtained by Kwékam et al. (2010) using the same method. The S-shape of the magnetic foliation and lineation trends in the Bandja pluton can allow us to consider the emplacement of the pluton in dextral shear context. 


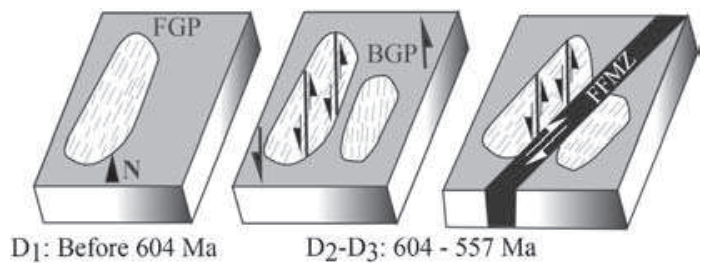

Figure 14. Sketch showing the tectonic history of the Bandja granitic pluton. FGP = Fomopéa granitic pluton; BGP = Bandja granitic pluton; FFMZ = Fotouni-Fondjomekwet mylonitic zone.

Sure enough, Ngako et al. (2003, 2008) and Ngako and Njonfang (2011) bring up the problem of left lateral wrench movement $(613-585 \mathrm{Ma})$ in the Pan-African belt and the sinistral shear event (613-590 Ma) accompanying the emplacement of granitoids in the belt. This lateral wrench motion develops the Buffle Noir Mayo Baleo (BNMB) shear zone (figure 1b), the Mayo Nolti shear zone (MNSZ), the Godé-Gourmaya shear zone (GGSZ) in the northern part of the belt and certainly the Rocher du Loup shear zone (RLSZ) along the southwestern coast of Cameroon. It appears as one of the three main tectonic events related to Pan-African collision and post-collision evolution identified in Cameroon, after the crustal thickening was initiated at $630 \mathrm{Ma}$ (Ngako and Njonfang 2011). According to Nguiessi Tchakam and Vialette (1994) and Nguiessi Tchakam et al. (1997), the Bandja granitic pluton units (charnockite and K-feldspar megacryst granite) are completely emplaced between 604 and 557 Ma. These ages can be reorganized as: (i) $686 \pm 17 \mathrm{Ma}$, age of metamorphism of banded gneiss, basement of $\mathrm{K}$-feldspar megacryst granite. This age is close to 687-633 Ma (earlier- $\mathrm{D}_{1}$ ) in the belt; (ii) 604-557 $\mathrm{Ma}$, as period of emplacement of the K-feldspar megacryst granite and its deformation through the dextral Pan-African $\mathrm{D}_{3}$ last event, recorded in the FFMZ, on the western part of the pluton. This reorganization seems in accordance with the tectonic evolution of the PBCA in Cameroon, to emplace the Bandja granitic pluton in a tectonic context initiated from the sinistral shear event of the Pan-African $\mathrm{D}_{2}$ to the dextral Pan-African $\mathrm{D}_{3}$ shear event, with the functioning of the Central Cameroon Shear Zone (CCSZ; Ngako et al. 2003, 2008; Ngako and Njonfang 2011). It also gives a good correlation with different tectonic events described in the Pan-African belt: crustal thickening and subsequent N-S to NNE-SSW sinistral wrench movement (630-530 Ma) and right lateral wrench movement (ca. 585-540 Ma).

According to Njiékak et al. (2008), the intrusion of the Batié porphyritic granite was dated at $602 \pm 1.4$ Ma. Njanko et al. (2010) dated the $\mathrm{D}_{2}$
$\mathrm{N}-\mathrm{S}$ striking sinistral deformation bands between 613 and $590 \mathrm{Ma}$ that integrate the $602 \pm 1.4 \mathrm{Ma}$ (U-Pb on zircons; Njiékak et al. 2008) on Batié porphyritic granite. The period ca. 602-590 Ma corresponds to the late Pan-African tectonomagmatic stage of the Batié area (Njiékak et al. 2008) and adjacent southern Bandja region. Magma emplacement of the Bandja feldspar megacryst granite is likely co-eval with movements along transcurrent dextral shear zones (figure 14).

\section{Conclusion}

The major conclusion of our work is that Bandja granitic pluton has a close relationship with granitic pluton of Fomopea and Batié pluton. This relationship can be guided through new results from the systematic study of magnetic fabric and microstructures that help to understand the emplacement of the Bandja pluton. AMS of Bandja pluton is controlled by ferromagnetic minerals that typically include MD magnetite. Moreover, continuous low field thermomagnetic curves (K-T curves) confirm magnetite as the main susceptibility carrier. The shape and orientation of the AMS ellipsoids defined a dominant triaxial-shape ellipsoid. The organization of $\mathrm{T}$ parameter diagram ( $\mathrm{T} v s$. $P^{\prime}$ ) correlates with the AMS projection diagrams of $\mathrm{K}_{1}, \mathrm{~K}_{2}$ and $\mathrm{K}_{3}$. The quantitative strain intensity indicator $P^{\prime}$ is also linked to the magnetite distribution in rocks than to the strain itself. The fabrics of the Bandja granitic pluton were acquired at the solid state deformation at high temperatures. Magnetic foliation and magnetic lineation trend an S-shape and allow to conclude that the complete emplacement and deformation of the pluton extends from the Pan-African $\mathrm{D}_{2}$ event to the dextral ENE-WSW Pan-African $\mathrm{D}_{3}$ shear event that occurred in the Pan-African belt in Cameroon and was related to the functioning of the Bandja $\mathrm{N} 30^{\circ} \mathrm{E}$ strike-slip shear zone that showed a dextral sense of motion.

\section{Acknowledgements}

We acknowledge Mbakop N and Petchou Z, who provided financial support for field trips and for the first author's stay in the Laboratory of Magnetism at the University Chouaïb Doukkali of El Jadida, Morocco. We thank Philippe Olivier (GET, France) for thermomagnetic analyses and curves; his comments have greatly improved this manuscript. We also thank the two referees, Teresa Roman-Berdiel and Ruth Soto, for their constructive suggestions. 


\section{References}

Archanjo C J, Launeau P and Bouchez J-L 1994 Magnetic fabrics vs. magnetite and biotite shape fabrics of the magnetite-bearing granite pluton of Gameleiras (northeast Brazil); Phys. Earth Planet. Interiors 89 63-75.

Benn K, Roest W R, Rochette P, Evans N G and Pignotta G S 1999 Geophysical and structural signatures of syntectonic batholith construction: The south Mountain Batholith, Meguma Terrane, Nova Scotia; Geophys. J. Interior. 136 144-158.

Blenkinsop T 2000 Deformation microstructures and mechanisms in minerals and rocks; Kluwer Academic Publishers, Dordrecht.

Borradaile G J 1988 Magnetic susceptibility, petrofabrics and strain; Tectonophys. 156 1-20.

Borradaile G J and Henry B 1997 Tectonic applications of magnetic susceptibility and its anisotropy; Earth Sci. Rev. $4249-93$.

Bouchez J L 1997 Granite is never isotropic: An introduction to AMS studies of granitic rocks; In: Granite: From segregation of melt to emplacement fabrics (eds) Bouchez J L, Hutton D H W and Stephens W E (Dordrecht: Kluwer Academic Publishers), pp. 95-112.

Bouchez J L 2000 Anisotropie de susceptibilité magnétique et fabrique des granites. Comptes Rendus Académie des Sciences, Paris; Earth Planet. Sci. 330 1-14.

Bouchez J L, Delas C, Gleizes G, Nédélec A and Cuney M 1992 Submagmatic microfractures in granites; Geology 20 $35-38$.

Brown M and Solar G S 1998 Granite ascent and emplacement during contractional deformation in convergent orogens; J. Struct. Geol. 20 1365-1393.

Dawaï D, Bouchez J L, Paquette J L and Tchameni R 2013 The Pan-African quartz-syenite of Guider (northCameroon): Magnetic fabric and $\mathrm{U}-\mathrm{Pb}$ dating of a lateorogenic emplacement; Precamb. Res. 236 132-144.

Day R, Fuller M D and Schmidt V A 1977 Interaction singledomain properties of magnetite intergrowth; J. Geophys. Res. 81 989-994.

Djouka-Fonkwé M L, Schulz B, Schüssler U C, Tchouankoué J P and Nzolang C 2008 Geochemistry of the Bafoussam Pan-African I- and S-type granitoids in western Cameroon; J. African Earth Sci. 50 148-167.

Dumort J C 1968 Carte géologique de reconnaissance à l'échelle 1/500 000 et notice explicative sur la feuille Douala-Ouest; Direction des mines et de la géologie du Cameroun.

Dunlop D J 1986 Hysteresis properties of magnetite and their dependence on particle size: A test of pseudosingle domain remanence models; J. Geophys. Res. 91 9569-9584.

Gregoire V, Darrozes J, Gaillot P, Nédélec A and Launeau P 1998 Magnetite grain shape fabric and distribution anisotropy vs. rock magnetic fabric: A 3D-case study; J. Struct. Geol. 20 937-944.

Hrouda F, Jelinek V and Zapletal K 1997 Refined technique for susceptibility resolution into ferromagnetic and paramagnetic components based on susceptibility temperature-variation measurement; Geophys. J. Int. $129715-719$.

Hrouda F and Janak F 1976 The changes in shape of the magnetic susceptibility ellipsoid during progressive metamorphism and deformation; Tectonophys. 34 $135-148$.

Hutton D W H 1997 Syntectonic granites and the principle of effective stress: A general solution to the space problem? In: Granite: From segregation of melt to emplacement fabrics (eds) Bouchez J L, Hutton D W $\mathrm{H}$ and Stephens W E (Dordrecht: Kluwer Academic Publishers), pp. 189-197.

Jelinek V 1978 Statistical processing of anisotropy of magnetic susceptibility measured on groups of specimens; Studia Geoph. Geod. 142 50-62.

Jelinek V 1981 Characterization of the magnetic fabric of rocks; Tectonophys. 79 563-567.

Kankeu B, Greiling R O and Nzenti J P 2009 Pan-African strike-slip tectonics in eastern Cameroon - Magnetic fabrics (AMS) and structure in the Lom basin and its gneissic basement; Precamb. Res. 174 258-272.

Kankeu B, Greiling R O, Nzenti J P, Bassahak J and Hell V J 2012 Strain partitioning along the Neoproterozoic central Africa shear zone system: Structures and magnetic fabrics (AMS) from the Meiganga area, Cameroon; Neues Jahrbuch für Paläontologie - Abhandlungen 265(1) 27-47.

Küster D and Liegeois J P 2001 Sr, Nd isotopes and geochemistry of the Bayuda Desert high-grade metamorphic basement (Sudan): An early Pan-African oceanic convergent margin, not the edge of the East Saharan ghost craton?; Precamb. Res. 109 1-23.

Kwékam M, Liégeois J P, Njonfang E, Affaton P, Hartmann G and Tchoua F 2010 Nature, origin and significance of the Pan-African high-K calc-alkaline Fomopéa plutonic complex in the Central African fold belt (Cameroon); J. African Earth Sci. 57 79-95.

Lagarde J L, Capdevila R and Fourcade S 1992 Granites et collision continentale: l'exemple des granitoïdes carbonifères dans la chaîne hercynienne ouest-europeenne; Bull. Soc. Géol. France 163 597-610.

Lamilen B D 1989 Contribution à l'étude du complexe anorogénique du Mont Koupé: un exemple de série alcaline incomplète, pétrologie et géochimie, Thèse de $3 e$ Cycle Univ. Yaoundé - Cameroun.

Mainprice D, Bouchez J L, Blumenfeld P and Tubia J M 1986 Dominant c-slip in naturally deformed quartz implications for dramatic plastic softening at high temperature; Geology 14 819-822.

Mamtani M A, Greiling R O, Karanth R V and Merh S S 1999 Orogenic deformation and its relationship to AMS fabric: An example from the southern margin of the Aravalli Mountain Belt, India; In: The Indian subcontinent and Gondwana: A palaeomagnetic and rock magnetic perspective (eds) Radhakrishna T and Piper J D, Geol. Soc. India Memoir 44 9-24.

McCaffrey K J W, Miller C F and Karlstrom K E 1999 Synmagmatic deformation patterns in the Old Woman Mountains, SE California; J. Struct. Geol. 21 335-349.

Mosoh Bambi C K, Frimmel H E, Zeh A and Suh C E 2013 Age and origin of Pan-African granites and associated U-Mo mineralization at Ekomedion, southwestern Cameroon; J. Afr. Earth Sci. 88 15-37.

Ngako V, Affaton P, Nnange J M and Njanko Th 2003 Pan-African tectonic evolution in central and southern Cameroon: Transpression and transtension during sinistral shear movements; J. Afr. Earth Sci. 36 207-214.

Ngako V, Affaton P and Njonfang E 2008 Pan-African tectonics in north-western Cameroon: Implication for the history of western Gondwana; Gondwana Res. 14 509-522.

Ngako V and Njonfang E 2011 Plates amalgamation and plate destruction, the western Gondwana history; Damien Closson, Intech edts, pp. 1-36.

Nguiessi Tchakam C T and Vialette Y 1994 Données géochronologiques ( $\mathrm{Rb}-\mathrm{Sr}, \mathrm{Pb}-\mathrm{Pb}, \mathrm{U}-\mathrm{Pb}$ ) sur le complexe plutonique de Bandja (Centre-Ouest Cameroun); Comptes Rendus Académie des Sciences (Paris) $\mathbf{3 1 9}$ 317-324. 
Nguiessi Tchakam C T, Nzenti J P, Nsifa N E, Tempier P and Tchoua F 1997 A calc-alkaline magmatic complex from Bandja in the north-equatorial fold belt: A synkinematic emplacement of plutonic rocks in a sinistral strikeslip shear zone from Pan-African age; Comptes Rendus Académie des Sciences (Paris) 325 95-101.

Njanko T, Nédélec A and Affaton P 2006 Synkinematic high-K calc-alkaline plutons associated with the PanAfrican central Cameroon shear zone (W-Tibati area): Petrology and geodynamic significance; J. Afr. Earth Sci. 44(4-5) 494-510.

Njanko T, Nédélec A, Kwékam M, Siqueira R and Esteban L 2010 Emplacement and deformation of the Fomopea pluton: Implication for the Pan-African history of western Cameroon; J. Struct. Geol. 32 306-320.

Njiékak G, Dörr W, Tchouankoué J P and Zulauf G 2008 $\mathrm{U}-\mathrm{Pb}$ zircon and microfabric data of (meta) granitoids of western Cameroon: Constraints on the timing of pluton emplacement and deformation in the Pan-African belt of central Africa; Lithos 102 460-477.

Nkoumbou C, Yonta Goune C, Villiéras F, Njopwouo D, Yvon J, Ekodeck G E and Tchoua F M 2006 Découverte des roches à affinité ophiolitique dans la chaîne panafricaine au Cameroun: Les talcschistes de Ngoung, Lamal Pougue et Bibodi Lamal; C. R. Geosci. 338 1167-1175.

Nzenti J P, Barbey P, Macaudière J and Soba D 1988 Origin and evolution of the Late Precambrian high-grade Yaounde gneiss (Cameroon); Precamb. Res. 38 91-109.

Nzenti J P 1998 Neoproterozoic alkaline meta-igneous rocks from the Pan-African north equatorial fold belt (Yaoundé, Cameroon): Biotitites and magnetic rich pyroxenites; J. Afr. Earth Sci. 26 37-47.

Paterson S R, Vernon R H and Tobisch O T 1989 A review for the identification of magmatic and tectonic foliations in granitoids; J. Struct. Geol. 11(3) 349-363.

Pearce J A, Harris N B W and Tindle A G 1984 Trace elements discrimination diagrams for the geotectonic interpretation of granite rocks; J. Petrol. 25 956-983.

Penaye J, Toteu S F, Van Schmus W R and Nzenti J P $1993 \mathrm{U}-\mathrm{Pb}$ and Sm-Nd preliminary geochronologic data on the Yaoundé series, Cameroon: Re-interpretation of the granulitic rocks as the suture of a collision in the "Centrafrican" belt; C.R. Acad. Sci. Paris $\mathbf{3 1 7}$ 789-794.

Penaye J, Kröner A, Toteu S F, Van Schmus W R and Doumnang J C 2006 Evolution of the Mayo Kebbi region as revealed by zircon dating: An early (ca. $740 \mathrm{Ma}$ ) PanAfrican magmatic arc in south-western Chad; J. Afr. Earth Sci. 44 530-542.

Petrovsky E and Kapicka A 2006 On determination of the Curie point from thermomagnetic curves; J. Geophys. Res. III B12S27, doi: 10.1029/2006JB004507.

Pignotta G S and Benn K 1999 Magnetic fabrics of the Barrington passage pluton, Meguma Terrane, Nova Scotia: A two-stage fabric history of syntectonic emplacement; Tectonophys. 307 75-92.
Rochette P 1987 Magnetic susceptibility of the rock matrix related to magnetic fabric; J. Struct. Geol. 9 1015-1020.

Rochette P, Jackson M and Aubourg C 1992 Rock magnetism and the interpretation of anisotropy of magnetic susceptibility; Rev. Geophys. 30 209-222.

Seme Mouangue A 1998 Géochimie, métamorphisme et métallogénie des formations ultrabasiques du secteur de Lomié (Sud-Est Cameroun); Thèse de Doctorat de 3è cycle Université de Yaoundé Cameroun, 150p.

Simpson C 1985 Deformation of granitic rocks across the brittle-ductile transition; J. Struct. Geol. 7 503-511.

Simpson C and Wintsch R P 1989 Evidence for deformation induced K-feldspar replacement by myrmekite; J. Metamor. Geol. 7 261-275.

Tagné Kamga G 2003 Petrogenesis of the Neoproterozoic Ngondo Plutonic complex (Cameroon, west central Africa): A case of late collisional ferro-potassic magmatism; J. Afr. Earth Sci. 36 149-171.

Tarling D H and Hrouda F 1993 The magnetic anisotropy of rocks; Chapman and Hall, London, 217p.

Tchameni R, Pouclet A, Penaye J, Ganwa A A and Toteu S F 2006 Petrography and geochemistry of the Ngaoundéré Pan-African granitoids in central north Cameroon: Implications for their sources and geological setting; J. Afr. Earth Sci. 44 511-529.

Tetsopgang S, Suzuki K and Njonfang E 2008 Petrology and CHIME geochronology of Pan-African high $\mathrm{K}$ and $\mathrm{Sr} / \mathrm{Y}$ granitoïds in the Nkambé area, Cameroon; Gondwana Res. 14 686-699.

Tetsopgang S, Anami M and Njonfang E 2006 Petrology of highly evolved Pan-African two-mica granites from the Nkambé area, west Cameroon; J. Afr. Earth Sci. 46 305-317.

Tetsopgang S, Suzuki K and Adachi M 1999 Preliminary CHIME dating of granites from the Nkambé area, northwestern Cameroon, Africa; J. Earth Planet. Sci. Nagoya University 46 57-70.

Toteu S F, Macaudière J, Bertrand J M and Dautel D 1990 Metamorphic zircons from northern Cameroon: implications for the Pan-African evolution of central Africa; Geologisch Rundschau 79 777-786.

Toteu S F, Van Schmus W R, Penaye J and Michard A 2001 New U-Pb and Sm-Nd data from north-central Cameroon and its bearing on the pre-Pan African history of central Africa; Precamb. Res. 108 45-73.

Toteu S F, Penaye J and Poudjom Djomani Y 2004 Geodynamic evolution of the Pan-African belt in central Africa with special reference to Cameroon; Canadian J. Earth Sci. 41 73-85.

Toteu S F, Penaye J, Deloule E, Van Schmus W R and Tchameni R 2006 Diachronous evolution of volcanosedimentary basins north of the Congo craton: Insights from $\mathrm{U}-\mathrm{Pb}$ ion microprobe dating of zircons from the Poli, Lom and Yaounde groups (Cameroon); J. Afr. Earth Sci. 44 428-442.

Vernon R H 2000 Review of microstructural evidence of magmatic and solid-state flow; Electr. Geosci. 5 2, ISSN 1436-2511. 